\title{
Ogólne zestawienie procesów w Sądzie Diecezjalnym w Tarnowie 1945-1983
}

Przedstawienie wyznaczonego tematu opracowania umożliwiają prowadzone w Sądzie Diecezjalnym w Tarnowie księgi procesowe. Interesujący nas zakres czasu zawiera się w ich 5 tomach - od drugiego do szóstego. Należy jednak uwzględnić także pierwszy tom, ponieważ zawiera nieliczne sprawy, które zakończyły się po 1945 roku. Pierwsza księga procesowa zawiera sprawy numerowane od 1 do 179, co oznacza, że wpłynęły one w latach 1933-1938. Druga księga odnotowuje sprawy numerowane od 180 do 419 i obejmuje lata 1938-1949. Tom trzeci zawiera sprawy od 420 do $816 \mathrm{z}$ lat 1949-1965. Czwarty tom ksiąg procesowych zawiera sprawy od 817 do 1218, co odpowiada latom 1965-1976. Piąta księga zawiera sprawy od 1219 do 1614, przypadające na lata 1976-1983. Ponadto 2 sprawy - 1615 i 1616 z 1983 roku - odnajdujemy w szóstym tomie ksiąg procesowych.

Następnym źródłem informacji na temat prowadzonych procesów mogą być sprawozdania przesyłane corocznie do Stolicy Apostolskiej przez poszczególne sądy kościelne. $\mathrm{W}$ archiwum sądowym odnajdujemy kopię pisma z Sekretariatu Przewodniczącego Episkopatu Polski Z 16 stycznia 1956 roku, które na polecenie ówczesnego przewodniczącego biskupa Michała Klepacza informowało o przypomnieniu Świętej Kongregacji Sakramentów o konieczności przesłania sprawozdań sądowych za miniony rok oraz zaległych od 1939 roku do 1954 roku, a także o obowiązku corocznego i regularnego przesyłania sprawozdań statystycznych 
począwszy od 1956 roku. Z początkowych lat interesującego nas okresu odnajdujemy w aktach sądowych jedynie kopię sprawozdania księdza oficjała Ignacego Dziedziaka z 14 stycznia 1950 roku'. Następnie możemy zauważyć fragmentaryczne sprawozdania księdza Stefana Zalesieńskiego za lata 1957-1970 wraz z krótkimi sprawozdaniami do Kurii Diecezjalnej, które miały stanowić kopię sprawozdania wysyłanego przez diecezję do Sekretariatu Prymasa Polski i Sygnatury Apostolskiej, łącznie z kopią przysięgi złożonej przez niego 25 kwietnia 1957 roku w związku z objęciem urzędu oficjała. W archiwum sądowym odnajdujemy następnie kopie sprawozdań księdza oficjała Piotra Gajdy wysyłane do Najwyższego Trybunału Sygnatury Apostolskiej zgodnie z nowymi kompetencjami tego trybunału nadanymi przez papieża Pawła vi w konstytucji Regimini Ecclesiae Universae z 15 sierpnia $1967 \mathrm{roku}^{2}$. Dokładny obraz w zakresie prowadzonych procesów w sądzie tarnowskim pozwalają także zobaczyć skorowidze toku spraw sądowych prowadzone przez księdza oficjała Zalesieńskiego w latach 1954-1970. Występują one w wersji dwujęzycznej- łacińskiej ${ }^{3}$ i polskiej ${ }^{4}$.

Należy zauważyć, że okres rozpatrywany przez niniejsze opracowanie to prawie 40 lat. Jest to czas niezwykle pasjonujący i obfitujący w wielkie wydarzenia w aspekcie ogólnoświatowym i kościelnym. Interesujący nas przedział czasu rozpoczyna się wraz z zakończeniem okupacji hitlerowskiej na ziemiach polskich i równocześnie $\mathrm{z}$ zakończeniem II wojny światowej, co bez wątpienia zaburzyło pracę Sądu Diecezjalnego w Tarnowie. Poddawany analizie okres działalności Sądu Diecezjalnego w Tarnowie to również czas epokowego wydarzenia dla Kościoła, jakim było zwołanie dwudziestego pierwszego soboru powszechnego. Został on otwarty 11 października 1962 roku przez papieża Jana XXIII, natomiast jego zakończenie przez papieża Pawła vi przypadło 8 grudnia

\footnotetext{
1 Por. I. Dziedziak, Constitutio Tribunalis anno 1949 pro causis matrimonialibus, 14.01.1950, Archiwum Sądu Diecezjalnego w Tarnowie [dalej: ASDT].

2 Por. Paulus vi, Regimini Ecclesiae Universae, „Acta Apostolicae Sedis” [dalej: AAs] 59 (1967), s. 885-928; Supremum Signaturae Apostolicae Tribunal, Litterae circulares ad praesides conferentiarum episcopalium de tribunalium ecclesiasticorum statu et activitate, AAS 63 (1971), s. 480-492.

3 Por. Causae matrimoniales anno: 1949, 1954-1961 definitae vel adhuc pendentes in dioecesi Tarnoviensi, ASDT.

4 Por. Sąd Diecezjalny w Tarnowie, Skorowidz toku spraw sądowych 1954-1970, ASDT.
} 
1965 roku, czyli niemal w połowie rozpatrywanego przez nas okresu. Omawiany w artykule czas kończy promulgacja ostatniego dokumentu Soboru Watykańskiego II - Kodeksu prawa kanonicznego Jana Pawła II - przez Konstytucję apostolską Sacrae disciplinae leges z 25 stycznia 1983 roku i jego wejście w życie - 27 listopada 1983 roku.

\section{Przedstawienie specyfiki spraw wpływających w latach 1933-1945, które zakończyły się po 1945 roku}

Możemy zauważyć wpływ wojny i okupacji na rozpatrywane bezpośrednio po nich tytuły toczących się spraw, a także na trudności dla trybunału w związku z dużą migracją ludzką, co często skutkowało umarzaniem wielu procesów, które rozpoczęły się wcześniej. Sąd kierował zapytanie do proboszczów parafii, gdzie zawarto poszczególne małżeństwa, po czym otrzymywał odpowiedź, że strony wyemigrowały. Tylko w pojedynczych przypadkach udawało się je zlokalizować za granicą, uzyskać od nich zeznania i doprowadzić sprawę do końca, jak chociażby było $\mathrm{w}$ przypadku stron przebywających w UsA w sprawie odnośnie do ich dopełnienia małżeństwa. Często proboszcz informował o śmierci jednej ze stron czy też decyzji o rezygnacji z dalszego prowadzenia sprawy z powodu choroby strony lub o jej braku zainteresowania dalszym prowadzeniem sprawy, a nawet o niemożności dotarcia do niej. Były także przypadki pogodzenia i następnie wspólnego życia.

Na podstawie ksiąg procesowych możemy obliczyć, że z lat 1933-1944 pozostało niezakończonych blisko 80 procesów. Wśród pozostałych do rozstrzygnięcia spraw prawie jedną czwartą stanowi rozpatrywana impotencja, która wraz z niedopełnieniem stanowi 40 proc. Zresztą $\mathrm{w}$ kilku przypadkach obserwujemy przekształcenie tytułu impotencji w niedopełnienie. Następnymi tytułami pokaźnie reprezentowanymi w tym okresie są przymus i bojaźń badane razem i sama bojaźń - stanowią blisko 20 proc. przyjętych tytułów. Jedną ósmą tytułów stanowi dwużeństwo. Po kilka spraw dotyczy braku formy kanonicznej, separacji, wady małżeńskiego konsensu. Spotykamy również pojedyncze sprawy dotyczące małżeństwa zawartego przy bliżej nieokreślonej przeszkodzie bez przewidzianej dyspensy oraz po jednej dotyczącej pokrewieństwa, choroby psychicznej i przestępstwa [por. Tabela 1, Wykres 1]. 
Tabela 1. Procesy 1933-1944 według tytułów

\begin{tabular}{cc}
\hline RozpatrywanY TYTUŁ NIEważNości & LiczBA \\
\hline impotentia (impotencja) & 18 \\
\hline inconsumatio (niedopełnienie) & 13 \\
\hline vis et metus (przymus i bojaźń) & 12 \\
\hline brak wyraźnie określonego tytułu & 9 \\
\hline bigamia (dwużeństwo) & 8 \\
\hline defectus formae (brak formy) & 5 \\
\hline separationis (separacja) & 4 \\
\hline defectus consensus (wada zgody) & 3 \\
\hline metus (bojaźń) & 3 \\
\hline nullitatis dispensationis (brak dyspensy) & 1 \\
\hline consanguinitatis (pokrewieństwo) & 1 \\
\hline amentia (zaburzenia psychiczne) & 1 \\
\hline criminis (występek) & 79 \\
\hline Razem & 1 \\
\hline
\end{tabular}

Znamienny jest fakt, iż w ponad połowie spraw pozostałych $\mathrm{z}$ lat przedwojennych i okresu wojny w blisko 50 proc. zostały one poniechane. Wśród przyczyn na pierwsze miejsce wysuwają się śmierć stron, ich migracja. W pojedynczych przypadkach to podjęcie wspólnego życia czy też życie osobne bez dalszego dochodzenia ważności małżeństwa, ciężka choroba strony. Znacznie mniej jest rezygnacji formalnych stron i jedynie 2 przypadki odrzucenia skargi z racji na brak świadectw ślubu i brak odpowiedzi strony. Wśród wspomnianej liczby jedynie 14 spraw zostało zakończonych wyrokiem, 9 przygotowanych do odesłania w sprawie dyspensy od małżeństwa zawartego i niedopełnionego, w 2 przypadkach wydano dekret nieważności bigamicznego małżeństwa i w 3 przypadkach stwierdzono jego nieważność z racji braku wymaganej formy. Wśród przyczyn 10 nierozstrzygniętych spraw znajdujemy sprzeczności w zeznaniach stron, brak zgody na poddanie się badaniu strony czy brak akt sprawy. Jedynie w 20 proc. spraw zostały wydane wyroki i w nieco ponad to proc. spraw poczyniono przygotowania do dyspensy papieskiej [por. Wykres 2]. 
Wykres 1. Procesy w latach 1933-1944 według tytułów

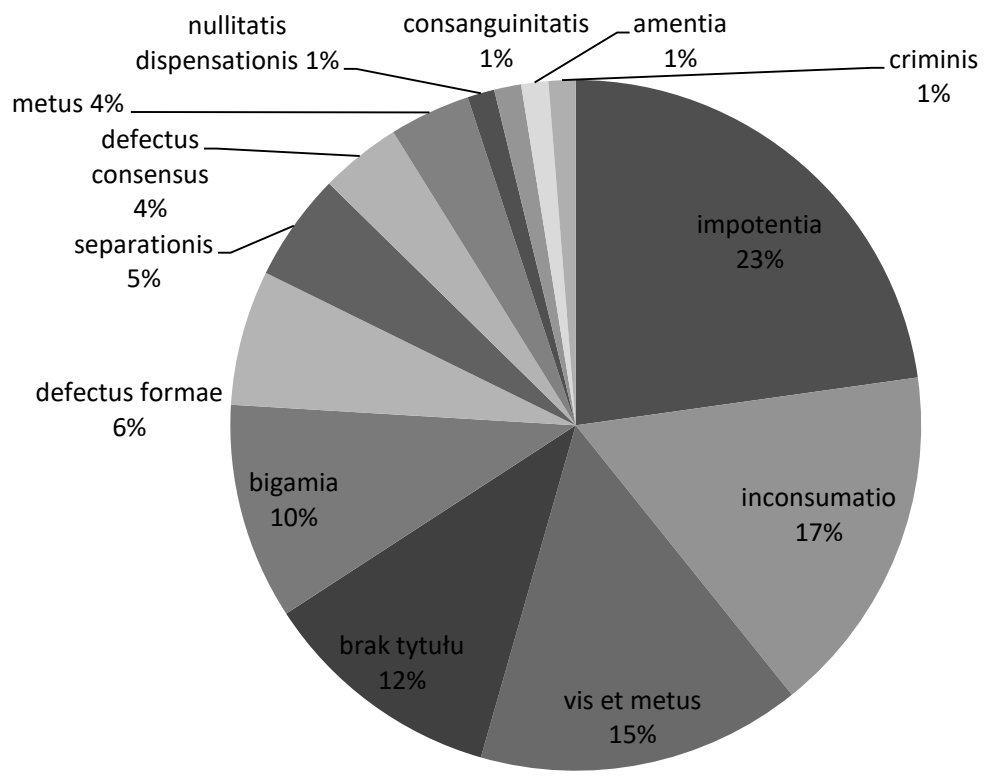

Wykres 2. Zakończenie spraw wcześniejszych po 1945 roku

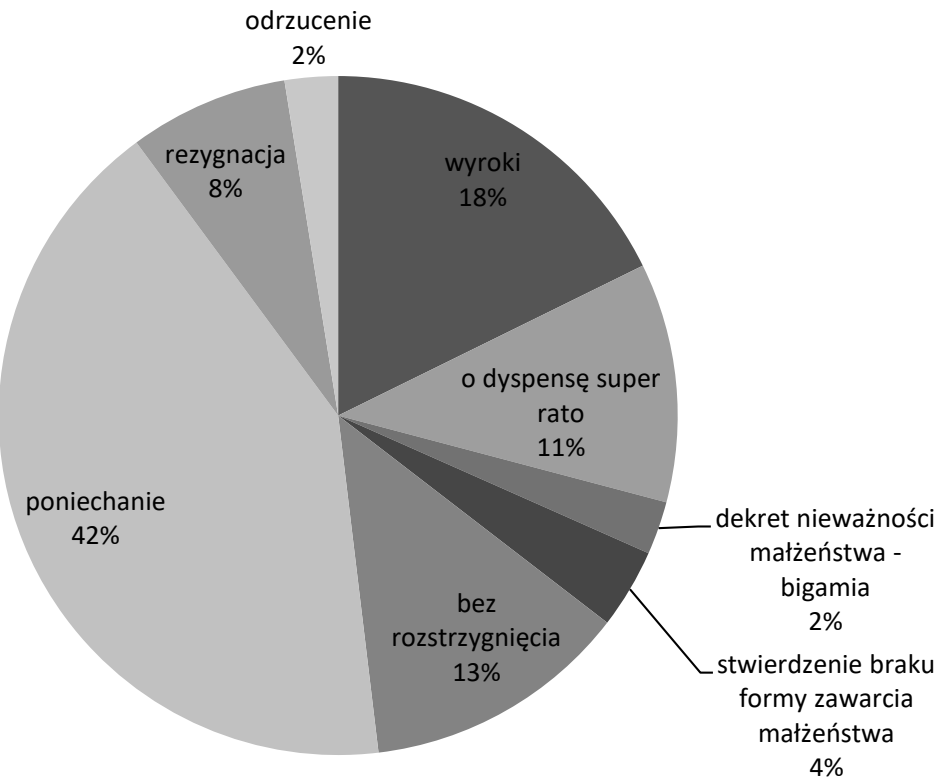


Tak więc po zakończeniu wojny stopniowo kończono sprawy wcześniej rozpoczęte; równocześnie zaczęły spływać nowe skargi. W księgach procesowych odnajdujemy 1334 numery procesów, które toczyły się w Sądzie Diecezjalnym w Tarnowie między 1945 a 1983 rokiem. Dla uchwycenia przemian zachodzących w procesach warto podzielić ten okres na 2 części: od zakończenia II wojny światowej do zakończenia Soboru Watykańskiego I i od 1966 roku do 1983 roku, kiedy wszedł w życie nowy kodeks.

\section{Zestawienie procesów $\mathrm{z}$ lat $1945-1965$}

Na początku interesującego nas przedziału czasowego nie obywało się bez trudności. W swoim sprawozdaniu z działalności sądowej ówczesny wiceoficjał Sądu Diecezjalnego w Tarnowie ksiądz doktor Ignacy Dziedziak pisał, że niemal wszystkie sprawy przed rokiem 1948 i 1947 są opóźnione, podając przy tym kilka przyczyn takiego stanu rzeczy. Po pierwsze wskazał na przygotowanie, celebrację i realizację III Synodu Diecezjalnego, w co sam był bardzo zaangażowany. Następnie wspomniał o chorobie poprzedniego oficjała - księdza prałata doktora Stanisława Bulandy, który odszedł z urzędu. Przede wszystkim ukazał jednak trudności występujące po wojnie, a związane ze zmianą zamieszkania, migracją i opuszczaniem diecezji, co utrudniało przesłuchania, a także z brakiem wystarczającej liczby kapłanów przygotowanych do pracy w sądzies.

\section{I. Jurysdykcja Kościoła w sprawach małżeńskich}

$\mathrm{Na}$ omawiany przedział czasu składają się 1334 rozpoczęte procesy, a także 79 spraw, które rozpoczęły się wcześniej i zakończyły po 1945 roku. Wśród nich prawie wszystkie są postępowaniami w sprawach małżeńskich, których tok prowadzenia regulują zarówno obowiązujący od 1917 roku do 1983 roku Kodeks prawa kanonicznego ${ }^{6}$, jak i instrukcja wydana przez Kongregację dla Sakramentów ${ }^{7}$. Zgodnie z prawem kanonicznym

\footnotetext{
5 Por. I. Dziedziak, Constitutio Tribunalis anno 1949 pro causis matrimonialibus, dz. cyt.

6 Codex Iuris Canonici, Pii X P.M. iussu digestus, Benedicti P. xv auctoritate promulgatus, AAS 9 (1917) pars II, s. 1-593 [dalej: KPK 1917], kan. 1960-1992.

7 Sacra Congregatio de Disciplina Sacramentorum, Instructio servanda a tribunalibus dioecesanis in pertractandis causis de nullitate matrimoniorum Provida Mater Ecclesia, AAS 28 (1936), s. 313-372 [dalej: PME], art. 1-240.
} 
sprawy małżeńskie między ochrzczonymi należą do sędziego kościelnego $^{8}$. Sprawami małżeńskimi w ścisłym znaczeniu są sprawy o ważność lub nieważność węzła małżeńskiego, o stwierdzenie dopełnienia lub niedopełnienia małżeństwa, o separację małżonków i ślubność potomstwa9 ${ }^{9}$. Pierwsza $\mathrm{z}$ wymienionych kategorii spraw stanowi 87 proc. aktywności sądu w zakresie rozpatrywanych tytułów w latach 1945-1965. Zaledwie 11 proc. stanowi kwestia dopełnienia małżeństwa. Przyczynami tak znacznej różnicy procentowej są zapewne dla stron procesowych utrudniony dostęp do Stolicy Apostolskiej i kosztowność takiej procedury. Zatem najpierw rozpatrywano ważność zaskarżonego małżeństwa $\mathrm{z}$ innych tytułów, najczęściej impotencji, a gdy one nie wychodziły i była podstawa do dyspensy, dokonywano przekształcenia. Na odnotowane 493 sprawy rozpoczynane z niezdolności 15 zostało przekształconych w niedopełnienie, których łącznie jest 63 . Wśród pozostałych spraw kilka dotyczy separacji, jedna domniemanej śmierci strony, brak spraw odnośnie do ślubności potomstwa [por. Wykres 3]. Zgodnie z jurysprudencją Stolicy Apostolskiej skutki czysto cywilne wynikające z małżeństwa należą do sądów świeckich ${ }^{10}$. Powyższe dane wynikają również z faktu, iż Stolica Apostolska tolerowała i aprobowała rozpoznanie spraw o separację małżonków przez sądy państwowe ${ }^{11}$.

${ }^{8}$ Por. KPK 1917, kan. 1960; PME, art. $1 \S 1$.

9 Por. F. Bączkowicz, Prawo kanoniczne. Podręcznik dla duchowieństwa, t. 3, wyd. 3, Opole 1958, s. 183.

${ }^{10}$ Por. KPK 1917, kan. 1016.

${ }^{11}$ Por. F. Bączkowicz, Prawo kanoniczne, dz. cyt., s. 184. 
Wykres 3. Sprawy małżeńskie w latach 1945-1965

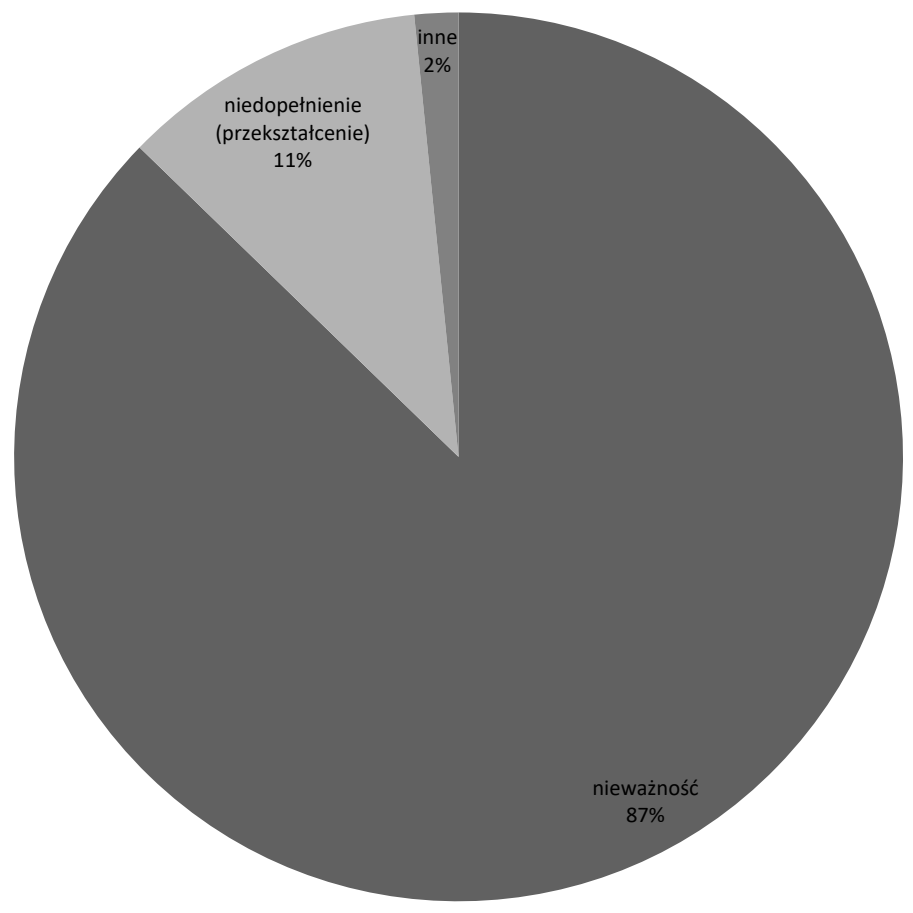

2.2. Właściwość sądu

Kompetencje sądu odnośnie do przyjęcia skargi określa kodeks z 1917 roku w kan. 1962-1965. Można tu mówić o właściwości rzeczowej. Zgodnie z nią sądy diecezjalne rozpatrują według tego uregulowania sprawy małżeńskie, które nie są zarezerwowane biskupowi Rzymu. Natomiast sprawy o rozwiązanie małżeństwa zawartego i niedopełnionego rozpoznają Kongregacja dla Sakramentów, Kongregacja dla Kościoła Wschodniego bądź Kongregacja Świętego Oficjum, w zależności od tego, czy strony przynależą do obrządku łacińskiego czy też jedna ze stron jest obrządku wschodniego bądź akatolicka ${ }^{12}$. Instrukcja Kongregacji dla Sakramentów Z 1923 roku daje możliwość sędziemu, który prowadził

\footnotetext{
12 Por. F. Bączkowicz, Prawo kanoniczne, dz. cyt., s. 185.
} 
proces z tytułu niezdolności płciowej i nie znalazł uzasadnienia dla impotencji, lecz niedopełnienia, przesłania na wniosek przynajmniej jednej strony akt do kongregacji wraz $\mathrm{z}$ tzw. opinią pro rei veritate. Natomiast w przypadku, gdy zebrane dowody nie są wystarczające do stwierdzenia niedopełnienia, powinny zostać uzupełnione i być przesłane wraz $\mathrm{z}$ opinią ordynariusza pro rei veritate oraz opinią obrońcy węzła pro tutela viculi. Taka możliwość wniesienia do Stolicy Apostolskiej prośby o dyspensę od małżeństwa zawartego i niedopełnionego dopuszczalna jest w przypadku rozpatrywania innych tytułów, które nie zostały udowodnione, ale odsłoniły prawdopodobieństwo niedopełnienia ${ }^{13}$. Te zasady odnajdujemy w praktyce Sądu Diecezjalnego w Tarnowie.

W szystkie właściwe sobie sprawy sądy diecezjalne rozpatrują w pierwszej instancji według przepisów o właściwości miejscowej. Właściwy do rozpatrywania sprawy jest sąd miejsca zawarcia małżeństwa (forum contractus) lub sąd miejsca zamieszkania stałego bądź tymczasowego strony pozwanej (forum domicilii vel quasi-domicilii); w przypadku gdy jedna strona jest akatolicka, właściwy jest sąd miejsca zamieszkania strony katolickiej ${ }^{14}$.

W przypadku zamieszkania tymczasowego konieczne było przeprowadzenie dochodzenia zgodnie z instrukcją Kongregacji dla Sakramentów na temat motywów obrania tej drogi kompetencyjnej ${ }^{15}$. Przytłaczająca większość spraw wpływających w latach 1945-1965 była prowadzona przy wzięciu pod uwagę miejsca zawarcia małżeństwa, bo aż 87 proc. Dopiero w dalszej kolejności właściwość określało zamieszkanie stron i zezwolenie prymasa Polski. W nielicznych przypadkach stwierdzono brak kompetencji po zbadaniu sprawy [por. Wykres 4].

13 Por. F. Bączkowicz, Prawo kanoniczne, dz. cyt., s. 185-186.

${ }^{14}$ Por. F. Bączkowicz, Prawo kanoniczne, dz. cyt., s. 187.

15 Por. F. Bączkowicz, Prawo kanoniczne, dz. cyt., s. 188. 
Wykres 4. Właściwość sądu w latach 1945-1965

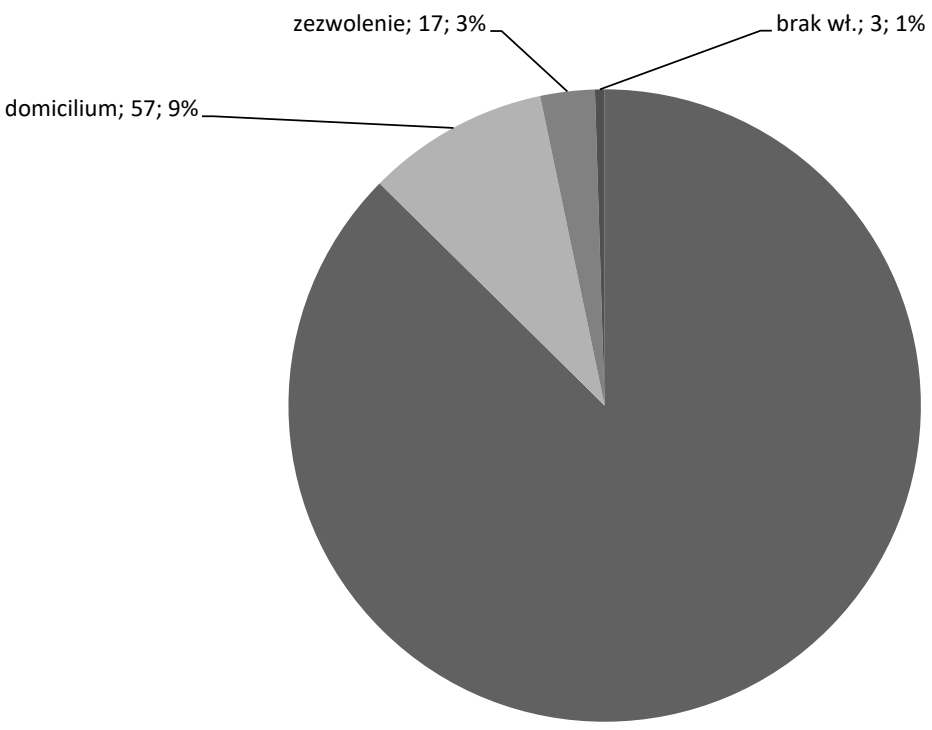

contractus; $534 ; 87 \%$

\subsection{Liczba spraw wpływających}

W latach 1945-1965 zostało przyjętych i wpisanych do ksiąg procesowych 549 spraw, co daje średnio na rok po 26 spraw. Ze zrozumiałych względów znacznie poniżej tej średniej plasuje się rok zakończenia wojny, w którym nie ma nawet 10 spraw. Kilkanaście spraw wpłynęło w latach 1951, 1958, 1960. Ponad 40 spraw przyjęto w omawianym okresie w 1947 roku oraz 1952 roku, ponad 30 przyjęto w latach 1949, 1950, 1953, 1955 [por. Tabela 2].

Tabela 2. Sprawy wpływające według osób wnoszących

\begin{tabular}{cccccc}
\hline RoK & SpraWy PRZYjęTe & Kobiety & MężCZý́Ni & Promotor & INNe \\
\hline 1945 & 9 & 3 & 6 & - & - \\
\hline 1946 & 27 & 20 & 6 & 1 & - \\
\hline 1947 & 43 & 24 & 19 & - & - \\
\hline 1948 & 26 & 13 & 13 & - & - \\
\hline 1949 & 37 & 16 & 21 & 1 & - \\
\hline 1950 & 30 & 17 & 13 & - & - \\
\hline
\end{tabular}


Ogólne zestawienie procesóww Sądzie Diecezjalnym...

\begin{tabular}{|c|c|c|c|c|c|}
\hline RoK & SPRAWY PRZYJĘTE & Ковіету & MĘŻCZYŹNI & PROMOTOR & INNE \\
\hline 1951 & 18 & 7 & 11 & - & - \\
\hline 1952 & 40 & 18 & 22 & - & - \\
\hline 1953 & 38 & 17 & 21 & - & - \\
\hline 1954 & 25 & 12 & 10 & - & 3 \\
\hline 1955 & 30 & 19 & 11 & - & - \\
\hline 1956 & 21 & 15 & 6 & - & - \\
\hline 1957 & 24 & 15 & 9 & - & - \\
\hline 1958 & 14 & 6 & 8 & - & - \\
\hline 1959 & 22 & 11 & 11 & - & - \\
\hline 1960 & 16 & 9 & 7 & - & - \\
\hline 1961 & 25 & 16 & 9 & - & - \\
\hline 1962 & 27 & 19 & 8 & - & - \\
\hline 1963 & 25 & 14 & 11 & - & - \\
\hline 1964 & 25 & 18 & 7 & - & - \\
\hline 1965 & 27 & 16 & 11 & - & - \\
\hline Razem & 549 & 305 & 240 & 2 & 3 \\
\hline
\end{tabular}

\subsection{Osoby wnoszące skargę}

Jak ustala Kodeks prawa kanonicznego, sąd nie może rozpatrywać sprawy małżeńskiej, jeśli nie wpłynęła najpierw formalna skarga ${ }^{16}$. Prawo zaskarżenia małżeństwa mają małżonkowie. Jednakże nie ma prawa zaskarżenia małżeństwa osoba, która przez rozmyślne i dobrowolne działanie stała się bezpośrednią przyczyną przeszkody zrywającej bądź nieważności małżeństwa ${ }^{17}$. Według tych uregulowań nie odmawia się małżonkowi prawa zaskarżenia własnego małżeństwa, gdy istnieje wątpliwość, czy był on bezpośrednio i rozmyślnie przyczyną przeszkody lub nieważności małżeństwa, przy czym nie traci on zdolności procesowej ${ }^{18}$. Zgodnie z prawem skargę może wnieść także promotor sprawiedliwości $\mathrm{w}$ przypadku przeszkód $\mathrm{z}$ natury publicznych ${ }^{19}$ lub na skutek doniesienia

\footnotetext{
16 Por. KPK 1917, kan. 1970; PME, art. 34.

17 Por. KPK 1917, kan. $1971 \$ 1$ n. 1 ; PME, art. $37 \$ 1$.

18 Por. F. Bączkowicz, Prawo kanoniczne, dz. cyt., s. 203.

19 Por. KPK 1917, kan. $1971 \$ 1$ n. 2.
} 
złożonego do ordynariusza bądź niego samego. Tak więc inne osoby nie mają bezpośredniego prawa zaskarżenia małżeństwa, nawet gdy są krewnymi, jedynie pośrednio przez poinformowanie ordynariusza lub promotora $^{20}$. Doniesienia może dokonać także nieuprawniony małżonek ${ }^{21}$. Istotny jest również zapis, zgodnie z którym jeśli małżonkowie mają prawo zaskarżenia własnego małżeństwa, a przeszkoda nie jest publiczna, należy nie uwzględniać owych doniesieńn ${ }^{22}$.

$\mathrm{W}$ interesującym nas przedziale czasowym przeważają skargi wniesione przez kobiety [por. Wykres 5]. Można powiedzieć, że jest to wyraźna różnica, ale nie druzgocąca. Możemy zauważyć kilka lat, gdy przeważają sprawy wniesione przez mężczyzn [por. Wykres 6]. Zaledwie w 2 przypadkach odnotowujemy sprawę wniesioną przez promotora, w wyniku przeszkody znanej publicznie, sprawę kończy dekret nieważności. Kilka innych wyszczególnionych spraw dotyczy procesów karnych bądź spornych, które odnajdujemy incydentalnie w księgach procesowych.

Wykres 5. Stosunek powództwa kobiet i mężczyzn w latach 1945-1965

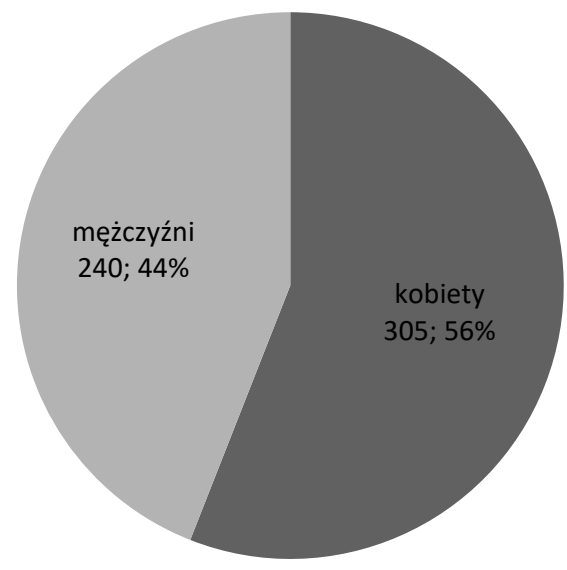

${ }^{20}$ Por. KPK 1917, kan. $1971 \S 2$; PME, art. $35 \$ 2$.

${ }^{21}$ Por. PME, art. $35 \$ 2$.

${ }^{22}$ Por. F. Bączkowicz, Prawo kanoniczne, dz. cyt., s. 208. 


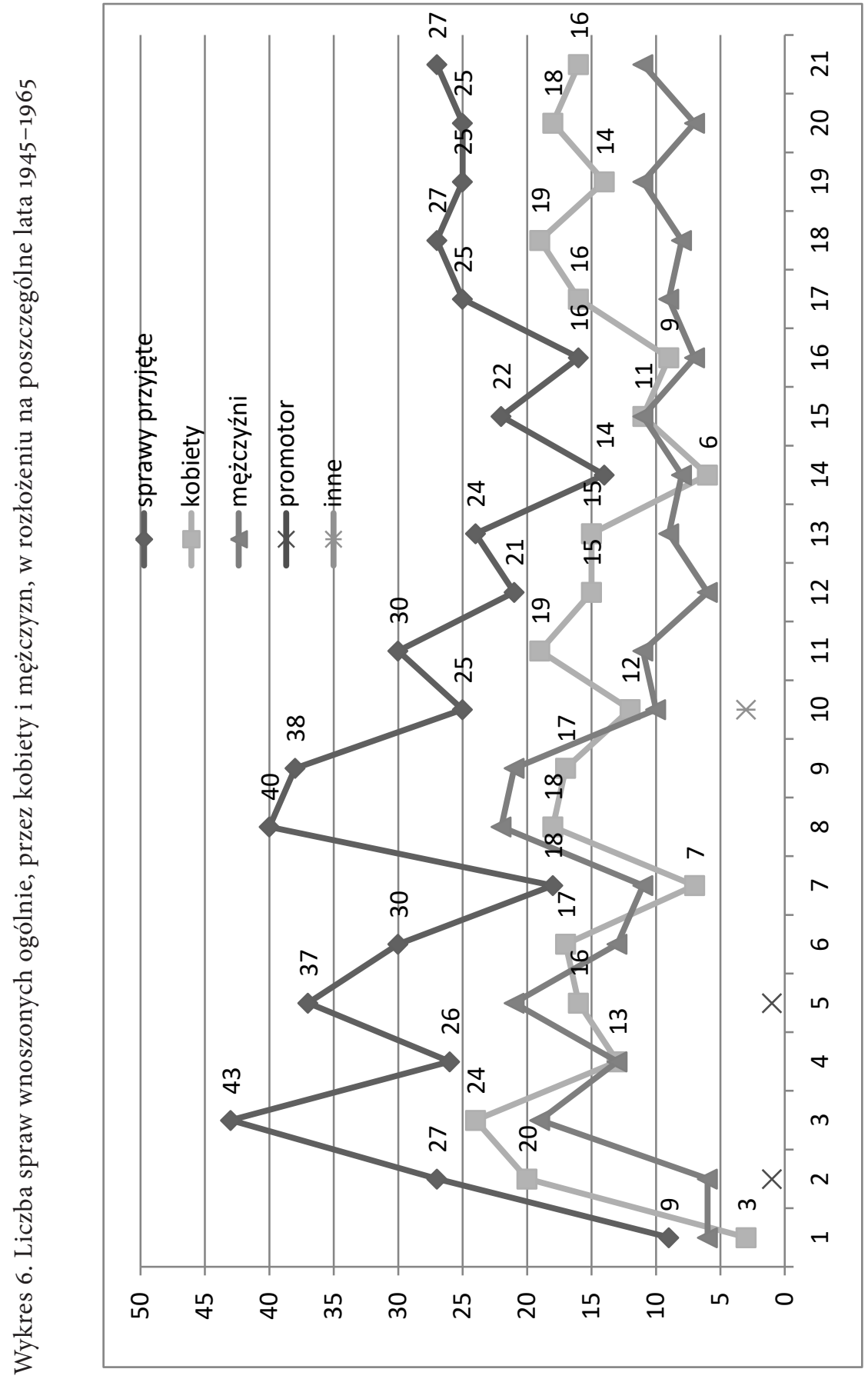




\subsection{Udział poszczególnych tytułów nieważności w sprawach wpływających w latach $1945^{-1965}$}

Tabela 3. Tytuły rozpatrywanych spraw w latach 1945-1965

\begin{tabular}{|c|c|}
\hline Tyтuє & LiczBA \\
\hline vis et metus (przymus i bojaźń) & 254 \\
\hline impotentia (impotencja) & 70 \\
\hline consensus fictus (pozorna zgoda) & 56 \\
\hline bigamia (dwużeństwo) & 48 \\
\hline amentia, morbus mentis (zaburzenia psychiczne) & 23 \\
\hline conditio (warunek) & 20 \\
\hline brak wyraźnie określonego tytułu & 20 \\
\hline inconsumatio (niedopełnienie) & 8 \\
\hline disparitas cultus (różnica religii) & 7 \\
\hline iurium (naruszenie praw) & 6 \\
\hline defectus consensus (wada zgody) & 6 \\
\hline ignorantia finis matrimonii (nieznajomość celów małżeńskich) & 5 \\
\hline consanguinitatis (pokrewieństwo) & 3 \\
\hline publica honestas (przyzwoitość publiczna) & 2 \\
\hline impedimentum criminis (występek) & 2 \\
\hline defectus debitae scientiae (brak wystarczającej wiedzy) & 2 \\
\hline actio de temporalibus (działalność doczesna) & 1 \\
\hline morbus venera (choroba weneryczna) & 1 \\
\hline affinitas (powinowactwo) & 1 \\
\hline raptus (uprowadzenie) & 1 \\
\hline defectus formae (brak formy) & 1 \\
\hline
\end{tabular}


Wykres 7. Udział poszczególnych tytułów w sprawach w latach 1945-1965

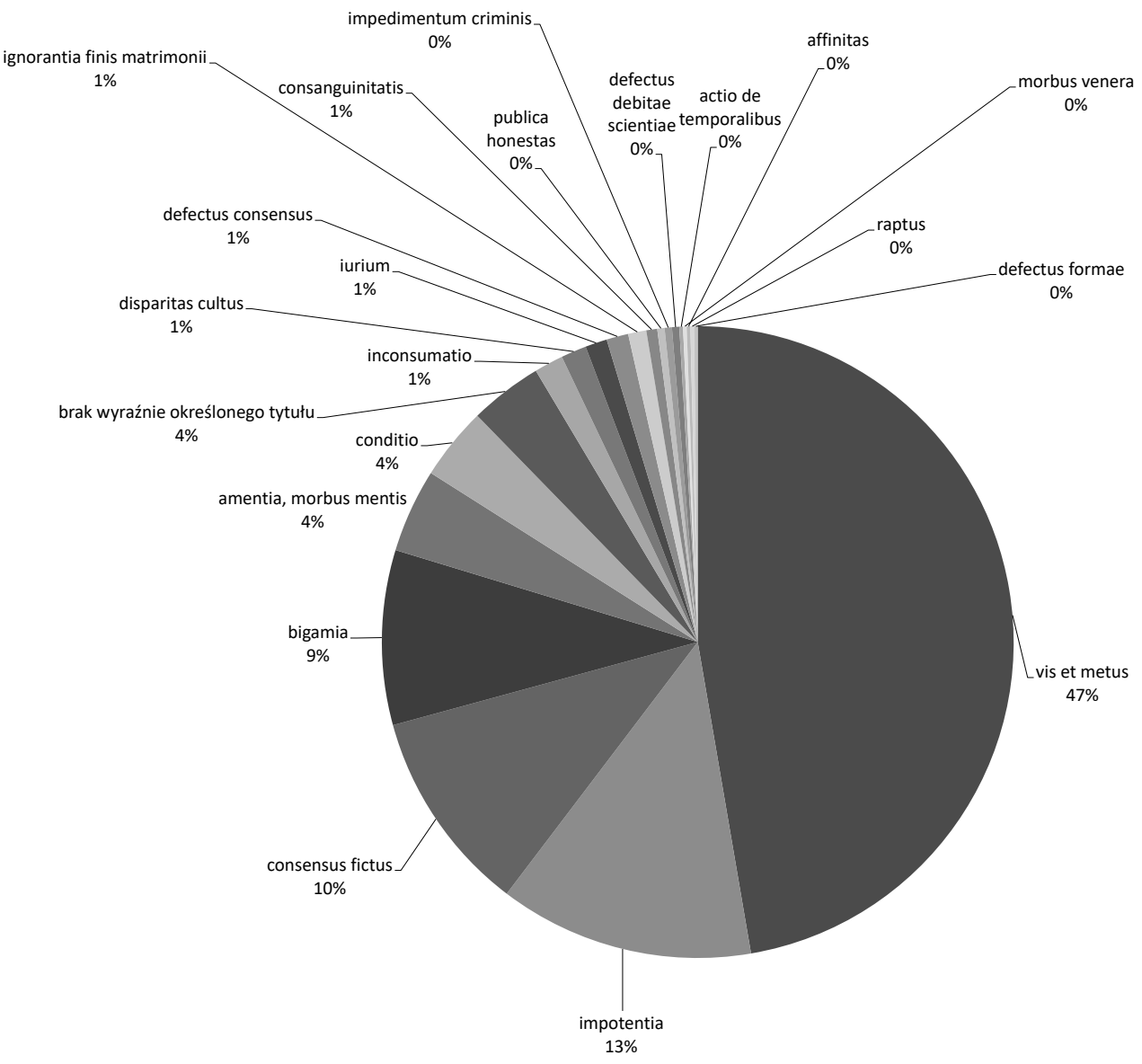

Wśród przyjętych tytułów przez Sąd Diecezjalny w Tarnowie w latach 1945-1965 dominuje tytuł przymusu i bojaźni, który stanowi niemal połowę rozpatrywanych przedmiotów sporu. Następnie wokół 10 proc. podejmowanych tytułów oscylują niezdolność płciowa, pozorna zgoda i bigamia. Po kilka procent dotyczy zaburzeń psychicznych i stawianych warunków. Pozostałe tytuły są incydentalne [por. Tabela 3, Wykres 7]. 


\subsection{Przyjęcie lub odrzucenie skargi}

Proces rozpoczyna wniesienie skargi powodowej. Zgodnie z instrukcją Kongregacji dla Sakramentów z 1936 roku skargi wpływające do sądu notariusz powinien odnotować, opatrzyć numerem dziennika i przedłożyć oficjałowi, który nadawał im dalszy bieg. Przewidziane było powoływanie sądu kolegialnego, który na pierwszym posiedzeniu wydawał postanowienie o przyjęciu bądź odrzuceniu sprawy ${ }^{23}$. Odnajdujemy w księgach procesowych skargi o nadanym kolejnym numerze procesu wraz $\mathrm{z}$ adnotacją o ich oddaleniu, w skorowidzach spotykamy także skargi, które oddalone były bez wpisania do ksiąg, po wcześniejszej analizie. Trudno podać dokładną liczbę skarg oddalonych w omawianym okresie, jednak na podstawie zliczenia dostępnych danych można powiedzieć, iż było to około 25 proc. ogółu wpływających skarg i stanowiło także poważną część aktywności oficjałów i poszczególnych sędziów [por. Wykres 8].

Wykres 8. Stosunek skarg przyjętych do oddalonych

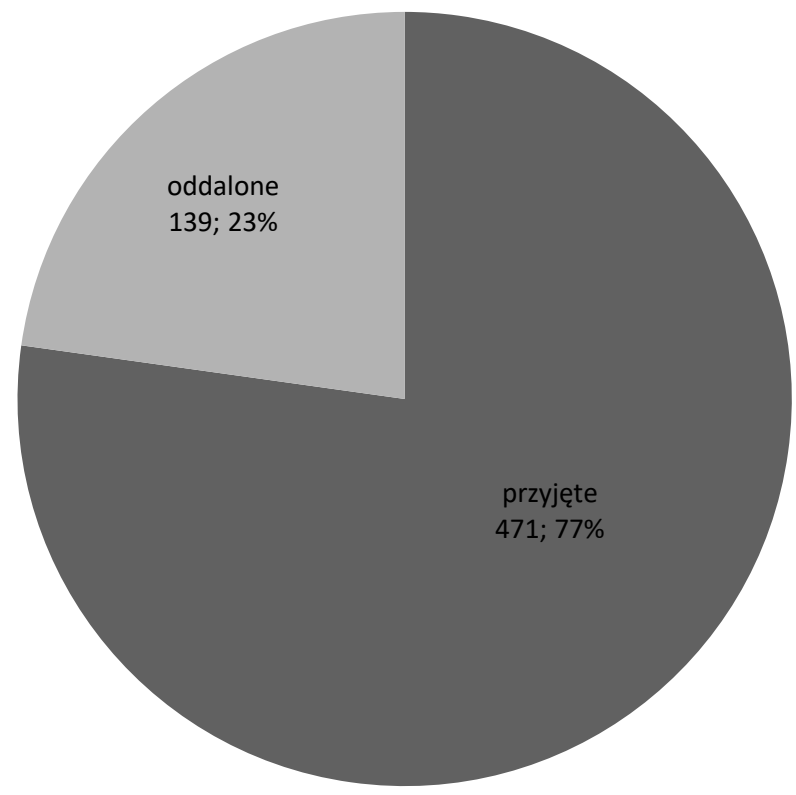

${ }^{23}$ Por. F. Bączkowicz, Prawo kanoniczne, dz. cyt., s. 216-217. 
W sprawozdaniach oficjałów zauważamy, iż w przypadku, gdy sprawy nie mogły być rozpatrzone w roku przyjęcia, były odkładane na następny rok. Mimo systematycznej pracy trybunału ich liczba narastała. Wzrost jest zauważalny w okresie bezpośrednio po wojnie, na co wpłynęły konieczność odnalezienia się w nowej sytuacji, organizacja synodu diecezjalnego i wspomniane wcześniej problemy kadrowe. Sytuacja stabilizuje się około 1950 roku, zmniejsza się liczba spraw pozostających. Zauważamy jednak falowość tej tendencji - ze spadkiem do czasu zwołania soboru i wzrostem w czasie jego trwania [por. Wykres 9].

Wykres 9. Sprawy pozostające do rozpatrzenia w poszczególnych latach 1945-1965

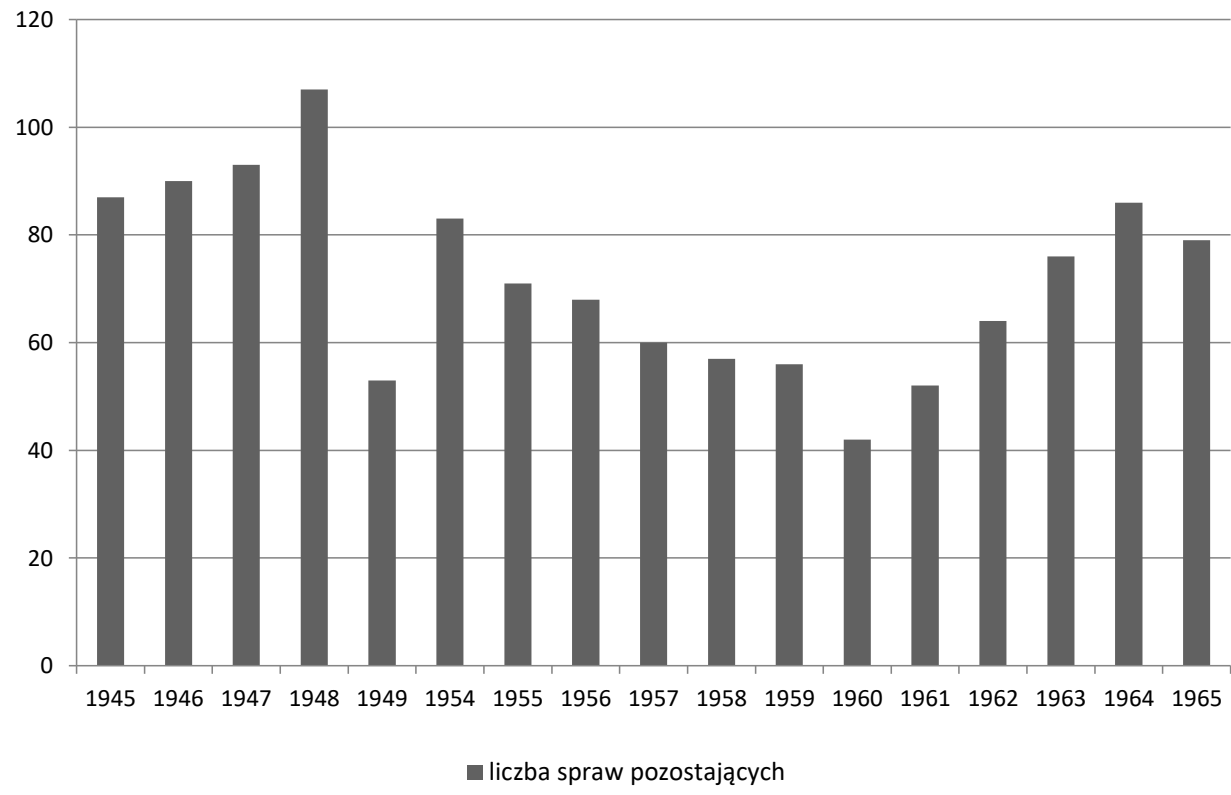


Głównymi dowodami w procesach kanonicznych są zeznania stron i świadków. W archiwum sądowym zachowały się zestawienia liczby godzin przesłuchań z lat 1955 i 1956 [por. Obraz 1, Obraz 2]. Oczywiście nie są one tylko wycinkiem pracy sędziów, którzy wypełniali funkcję ponensa, gromadząc dowody procesowe w celu poznania pełnej prawdy o małżeństwie, potwierdzenia jego ważności, możliwości ewentualnej konwalidacji czy też orzeczenia jego nieważności. Obok tego księgi procesowe, skorowidze i sprawozdania informują o dokładnym przydziale spraw i poszczególnych funkcji w ramach sądów kolegialnych.

Obraz 1. Roczne zestawienie liczby godzin przesłuchań z 1955 roku

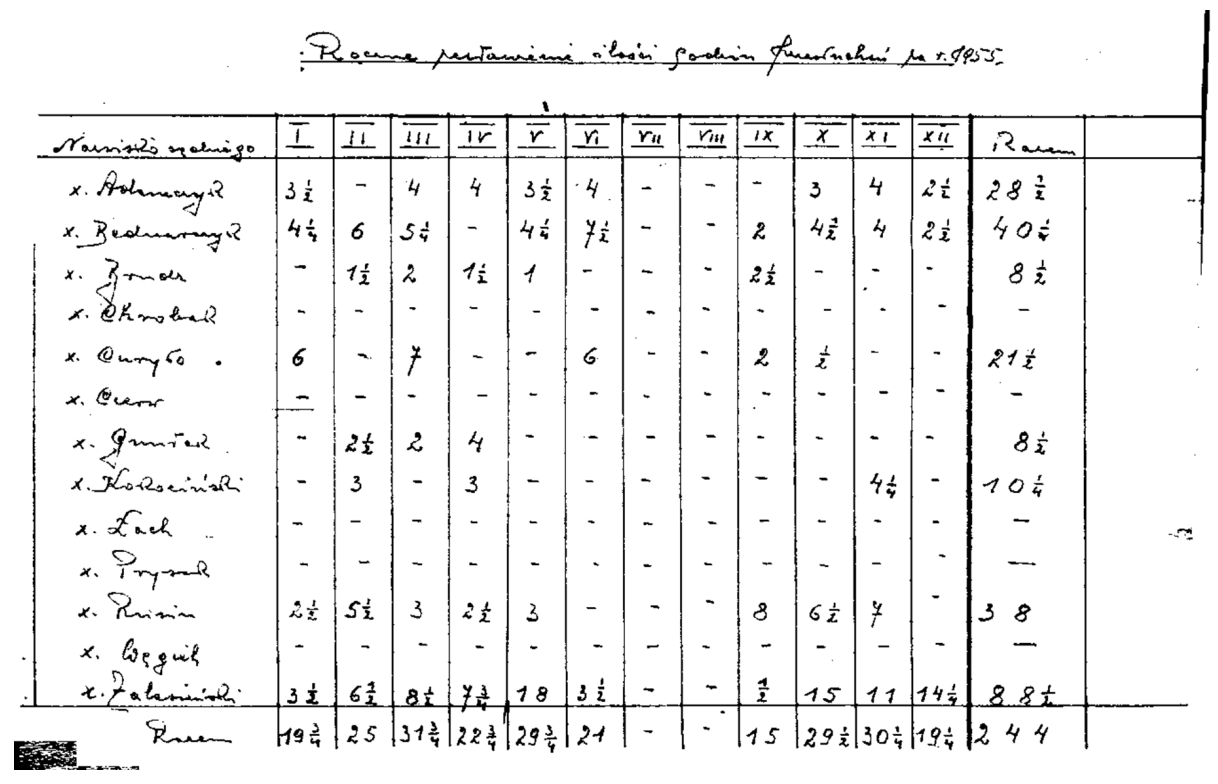


Obraz 2. Roczne zestawienie liczby godzin przesłuchań z 1956 roku

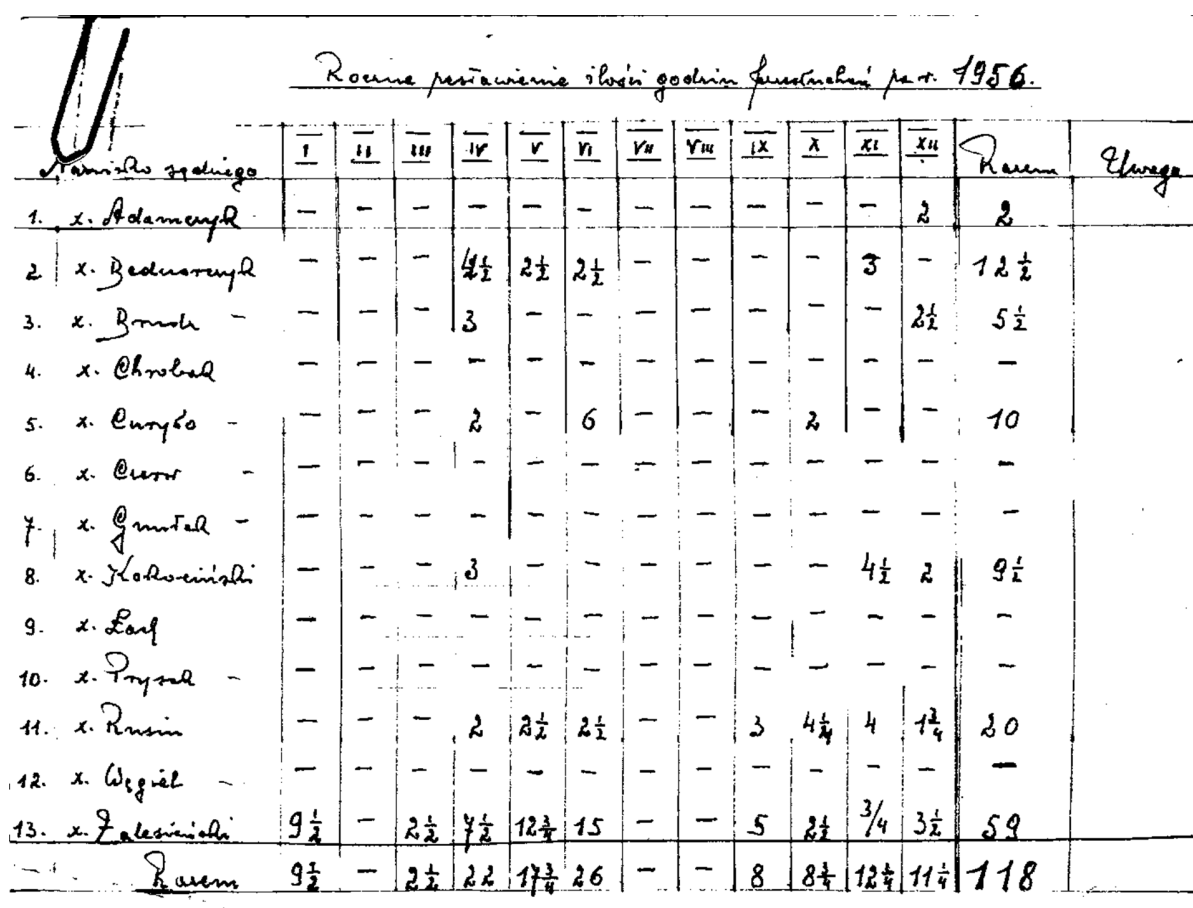

\subsection{Zakończenie instancji}

Instancja kończy się wyrokiem lub różnymi innymi rodzajami zakończenia sprawy (causa finita), które są wynikiem porzucenia (causa derelicta, deserta), zrzeczenia się instancji (renuntiatio), umorzenia (causa perempta) czy nawet odrzucenia samej skargi (libella reiecta). Obok wyroków wydanych zgodnie z procedurą zwyczajną, wymaganych do wykonalności drugiego pozytywnego wyroku bez apelacji, obserwujemy postępowania skrócone ${ }^{24}$, które miały zastosowanie w przypadku niebudzącej wątpliwości nieważności wynikającej z przeszkody: różnej religii, węzła małżeńskiego, pokrewieństwa, powinowactwa; nie odnotowujemy natomiast postępowań skróconych z powodu wyższych święceń,

\footnotetext{
${ }^{24}$ Por. KPK 1917, kan. 1990-1992.
} 
uroczystego ślubu czystości czy pokrewieństwa duchowego. W wymienionych przypadkach wydawano dekret nieważności małżeństwa bez konieczności zatwierdzenia drugim wyrokiem [por. Tabela 4].

Tabela 4. Zakończenie instancji w latach 1945-1965

\begin{tabular}{|c|c|c|c|c|}
\hline RoK & $\begin{array}{c}\text { WYrok } \\
\text { POZYTYWNY }\end{array}$ & $\begin{array}{c}\text { WYROK } \\
\text { NEGATYWNY }\end{array}$ & $\begin{array}{l}\text { ZAKOŃCZONE } \\
\text { BEZ WYROKU }\end{array}$ & $\begin{array}{c}\text { VOTA } \\
\text { SUPER RATO }\end{array}$ \\
\hline 1945 & 2 & 1 & 1 & - \\
\hline 1946 & 8 & 1 & 8 & 3 \\
\hline 1947 & 7 & 4 & 25 & 4 \\
\hline 1948 & 4 & - & 2 & - \\
\hline 1949 & 22 & 15 & 54 & 8 \\
\hline 1950 & 24 & 11 & 19 & 14 \\
\hline 1951 & 2 & 3 & 5 & - \\
\hline 1952 & 12 & 1 & 20 & 4 \\
\hline 1953 & 10 & 7 & 23 & 1 \\
\hline 1954 & 6 & 4 & 11 & 1 \\
\hline 1955 & 14 & 5 & 27 & 1 \\
\hline 1956 & 16 & 6 & 12 & 2 \\
\hline 1957 & 9 & 4 & 11 & 1 \\
\hline 1958 & 9 & 11 & 13 & 2 \\
\hline 1959 & 18 & 6 & 8 & 2 \\
\hline 1960 & 6 & 7 & 12 & - \\
\hline 1961 & 10 & 5 & 5 & - \\
\hline 1962 & 10 & 4 & 5 & - \\
\hline 1963 & 11 & 3 & 2 & 1 \\
\hline 1964 & 15 & 11 & 10 & 3 \\
\hline 1965 & 15 & 8 & 2 & 4 \\
\hline Razem & 230 & 117 & 275 & 51 \\
\hline
\end{tabular}


Wykres 10. Bilans procesów pozytywnych i negatywnych w latach 1945-1965

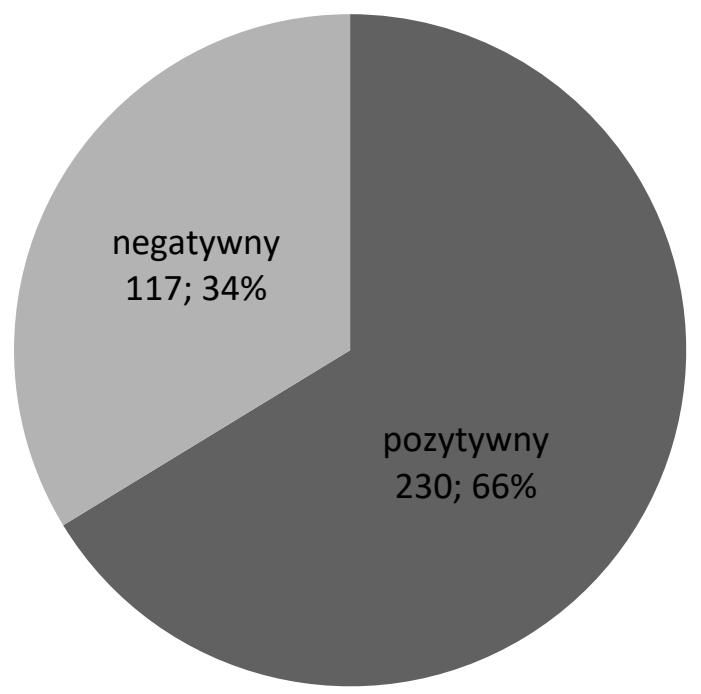

Wykres 11. Zestawienie procentowe zakończenia instancji w latach 1945-1965

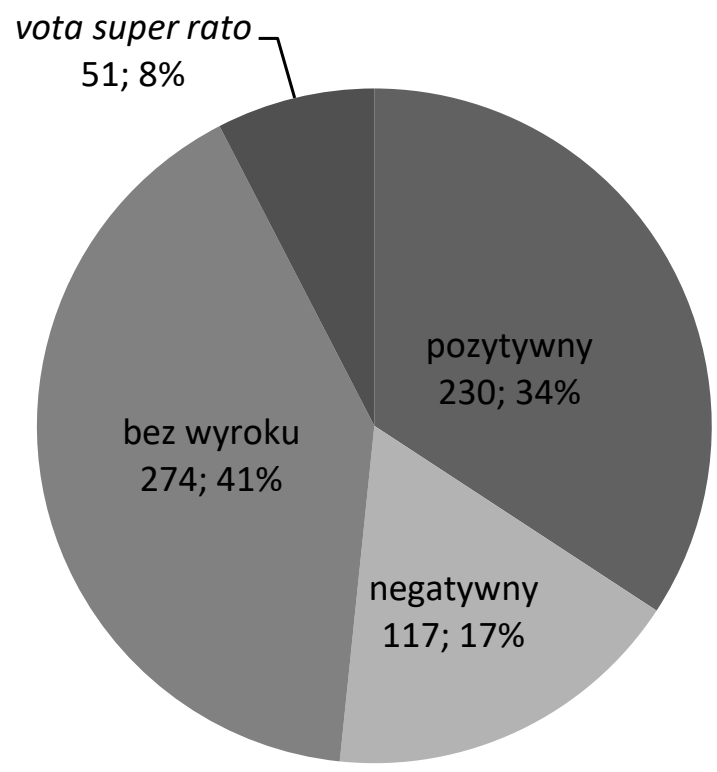


Zauważamy, iż w latach 1945-1965 spośród wydanych wyroków 67 proc. stanowią wyroki pozytywne. Jednakże zastanawiający jest fakt, że w opisywanym okresie 40 proc. spraw zostało bez wyroku. Jest to niewątpliwie skutkiem pozostania wielu spraw sprzed wojny, które z różnych przyczyn stały się nieaktualne, a także tego, iż zanim sprawy zostawały przyjęte do procesu, były poddawane analizie [por. Wykres 10, Wykres 11]. Wśród pozytywnych rozstrzygnięć na pierwszym miejscu plasuje się tytuł przymusu i bojaźni - blisko połowa pozytywnych rozstrzygnięć. Wokół 10 proc. oscylują bigamia, sprawy zakwalifikowane do dyspensy papieskiej, impotencja i pozorna zgoda. Kilka procent stanowią tytuły dotyczące małżeństwa zawartego pod warunkiem i zaburzeń psychologicznych. Pozostałe tytuły są incydentalne [por. Wykres 12].

Wykres 12. Udział poszczególnych tytułów w rozstrzygnięciach pozytywnych spraw w latach 1945-1965

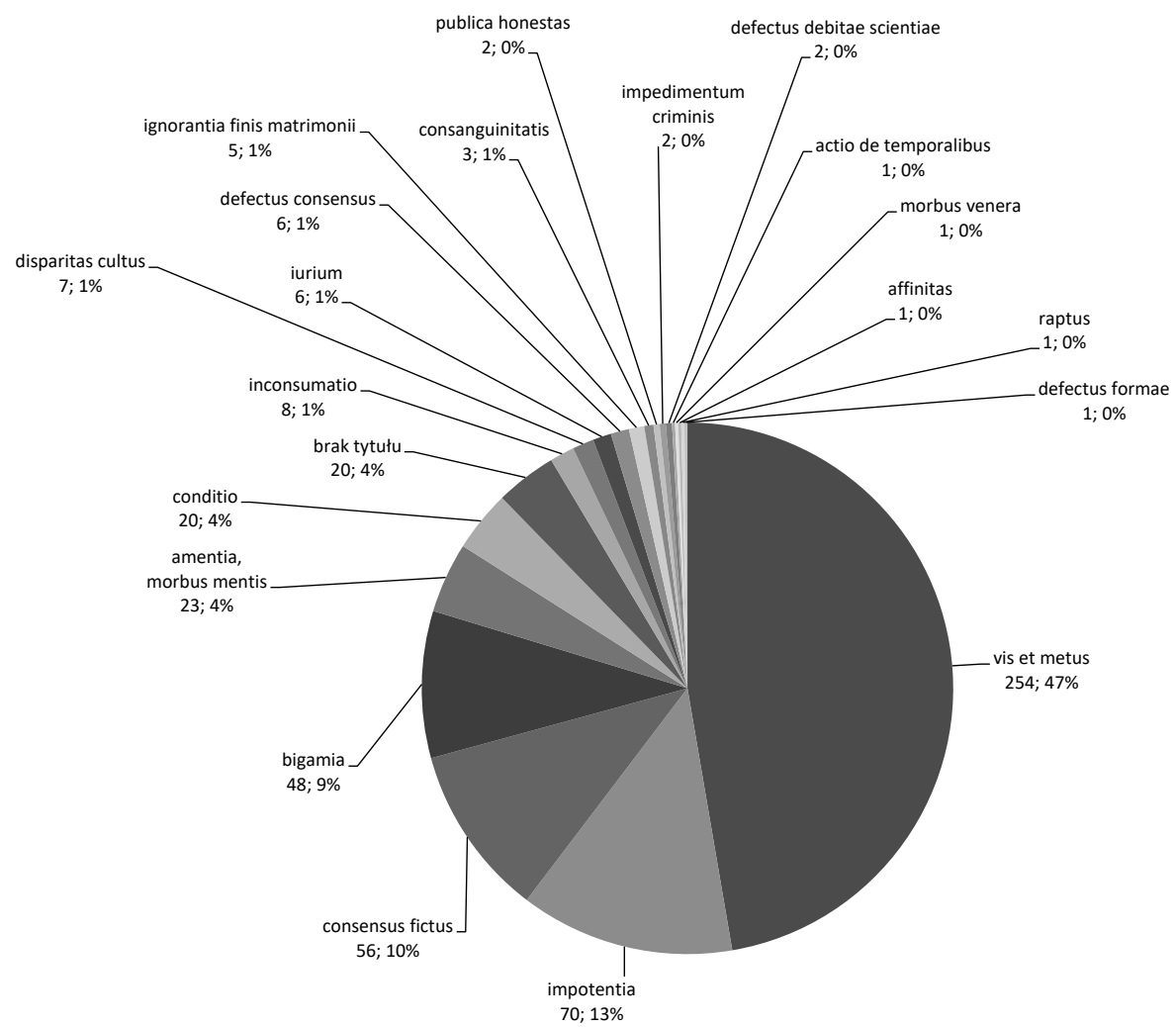


Przymus i bojaźń jako najczęściej rozważany tytuł pojawia się także na pierwszym miejscu wśród sentencji negatywnych i stanowi prawie połowę tego rodzaju wyroków. Na kolejnych miejscach plasują się: pozorna zgoda, impotencja [por. Wykres 13].

Wykres 13. Udział poszczególnych tytułów w rozstrzygnięciach negatywnych

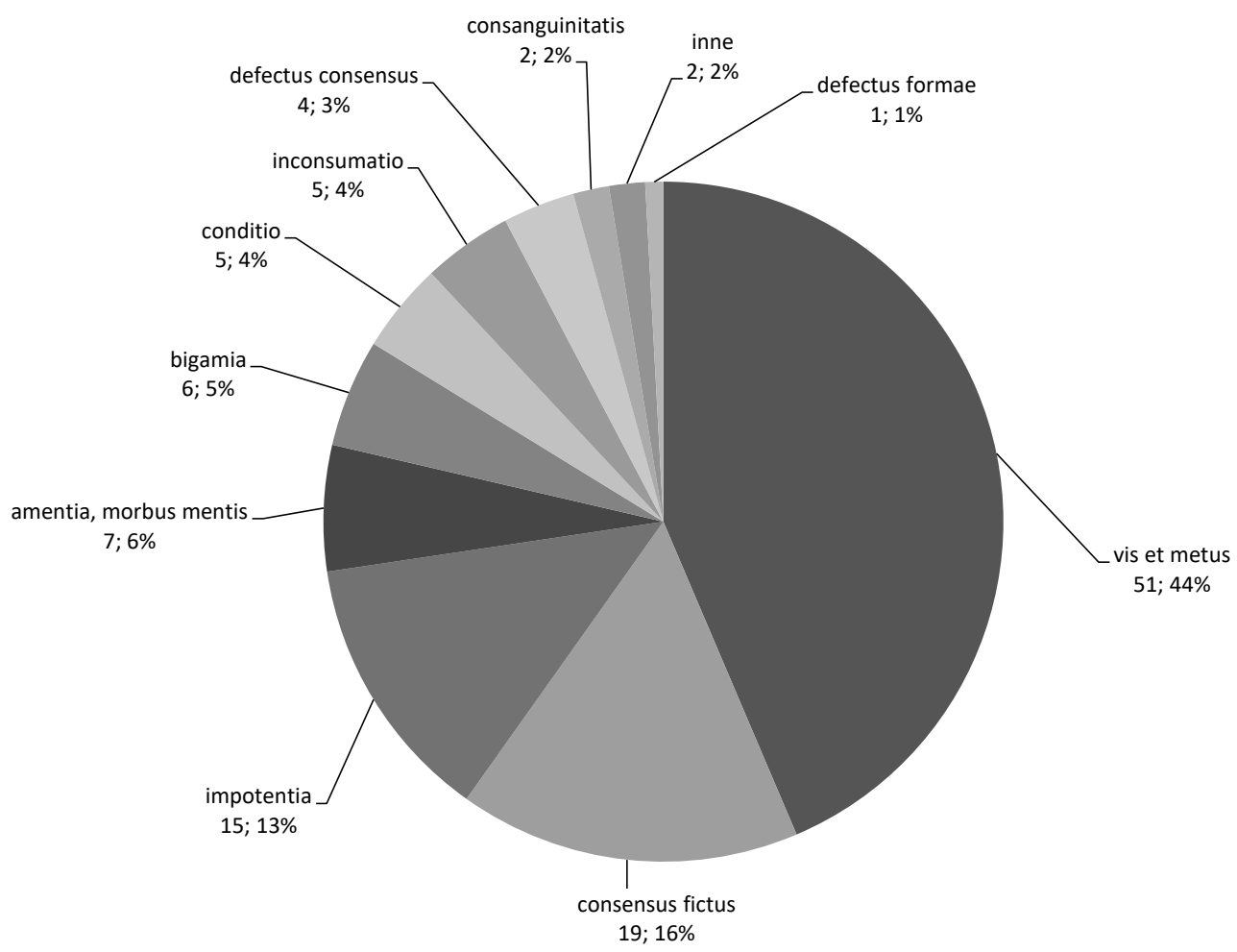




\section{Zestawienie procesów po Soborze Watykańskim II}

W okresie następującym po Soborze Watykańskim obserwujemy dalszą tendencję wzrostu procentowego spraw o stwierdzenie nieważności do ponad 90 proc. w stosunku do super rato [por. Wykres 14]. Być może było to spowodowane względami ekonomicznymi, sądy prowadziły więc najpierw inne tytuły. Gdy one nie wyszły i była podstawa do ubiegania się o dyspensę papieską, to uskuteczniano tę drogę.

Wykres 14. Rodzaj postępowania w sprawach małżeńskich w latach 1966-1983

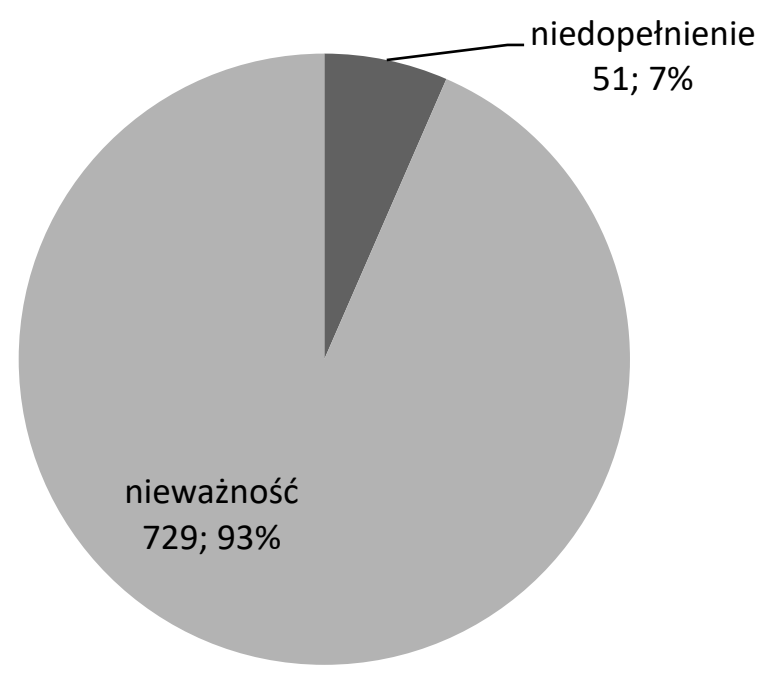

3.I. Właściwość trybunału

Wydane przez papieża Pawła vi motu proprio Causas matrimoniales z 28 marca 1971 roku nieco precyzuje kwestie związane z kompetencją trybunału. Pozostaje miejsce zawarcia małżeństwa, ale w przypadku zamieszkania strony pozwanej mowa o konieczności udowodnienia przy pomocy dokumentacji kościelnej ${ }^{25}$. Pojawia się trzecia możliwość kompetencji - miejsca gromadzenia większości dowodów, z wymogiem

${ }^{25}$ Por. Paulus vi, Motu Proprio Causas Matrimoniales, w: C. Lefebvre, Il motu proprio „Causas matrimoniales”, Torino 1972, s. 11-12. 
uprzedniej zgody ordynariusza miejsca zamieszkania strony pozwanej ${ }^{26}$. Od 1975 roku pojawiają się sprawy opierające się na tej możliwości. Poza tym mamy kilka spraw zleconych bezpośrednio przez Stolicę Apostolską jako trzecia instancja, a także pojedyncze sprawy prowadzone na mocy zezwolenia prymasa Polski. Z miejsca zawarcia małżeństwa wynika 95 proc. spraw [por. Wykres 15].

Wykres 15. Kompetencja trybunału 1966-1983

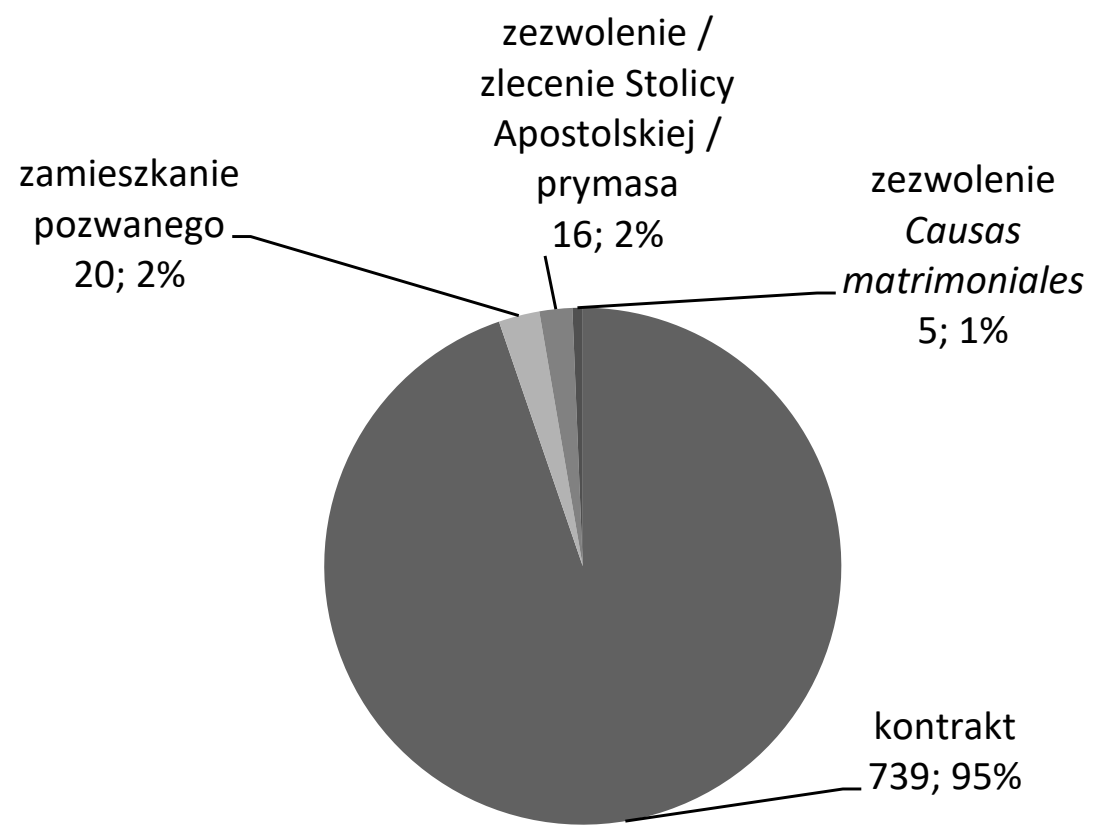

3.2. Sprawy wpływające i przyjęte do procesu

Chociaż nie dysponujemy dokładnym rejestrem skarg wpływających w interesującym nas okresie, to na podstawie danych zgromadzonych możemy stwierdzić, że w latach 1966-1983 wpływało już średnio około 8o skarg rocznie; znaczny ich procent po wstępnej analizie odrzucano w ramach rozpatrywania informacyjnego, na co dużo czasu poświęcali poszczególni sędziowie. Skargi odrzucone były zachowywane w archiwum sądu jako tzw. Acta reiecta. Obserwujemy zatem wzrost procentowy oddalanych

${ }^{26}$ Por. Paulus vi, Motu Proprio Causas Matrimoniales, dz. cyt., s. 12. 
skarg w porównaniu do poprzednio analizowanego okresu - niemal o 20 proc. Mimo wszystko do dalszego rozpatrywania przyjmowano blisko 60 proc. spraw. Zapewne było to efektem polepszenia sytuacji kadrowej, wpływającego na możliwość dokładnej analizy spraw oraz kontaktu z osobami wnoszącymi skargę, co wcześniej było utrudnione ze względu na sytuacje losowe. Niewątpliwie wymagania bezpośrednio po wojnie były mniejsze, uwarunkowane sytuacją zewnętrzną. Teraz sytuacja uległa zmianie [por. Wykres 16, Wykres 17].

Wykres 16. Skargi przyjęte a oddalone

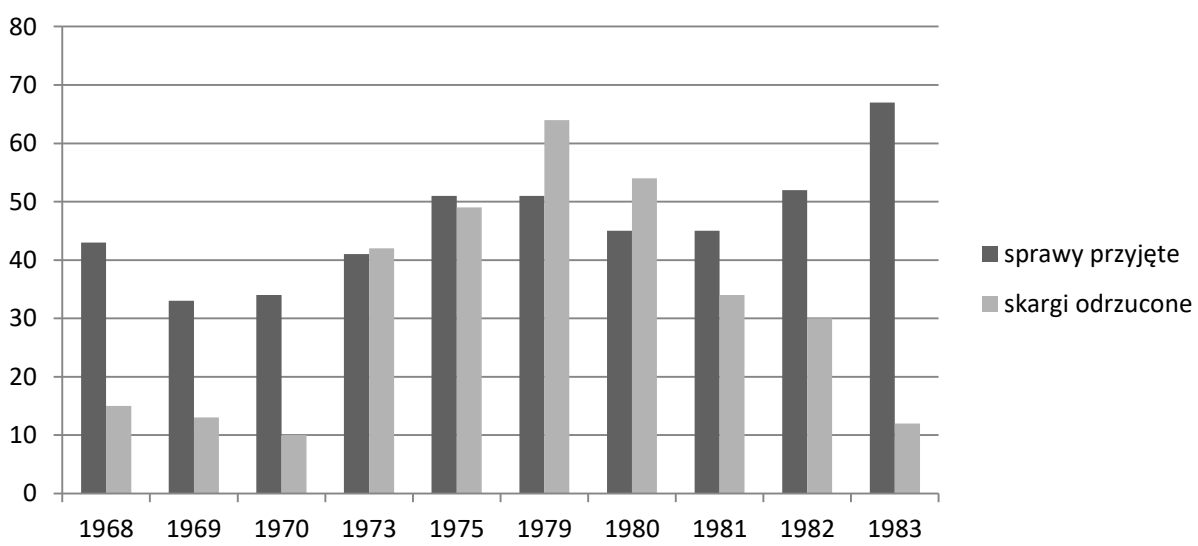

Wykres 17. Udział procentowy skarg przyjętych do procesu i oddalonych

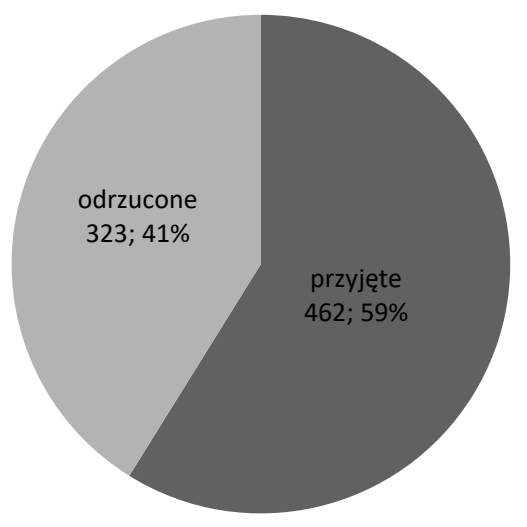


Po Soborze Watykańskim iI obserwujemy wzrost przyjmowanych do procesu spraw, których średnia w rozpatrywanym okresie wynosi 43 na rok. Dalej większość spraw wnoszą kobiety, jednakże różnica jest nieznaczna - 52 proc. do 48 proc., zatem zmniejsza się w porównaniu do pierwszego $z$ omawianych zakresów czasu. W okresie tym, jak we wcześniejszym, również można zaobserwować lata, gdy to mężczyźni wnoszą więcej spraw [por. Wykres 18, Wykres 19]. Nie odnotowujemy udziału promotora sprawiedliwości.

Wykres 18. Liczba spraw przyjętych w rozłożeniu na osoby wnoszące w latach 1966-1983

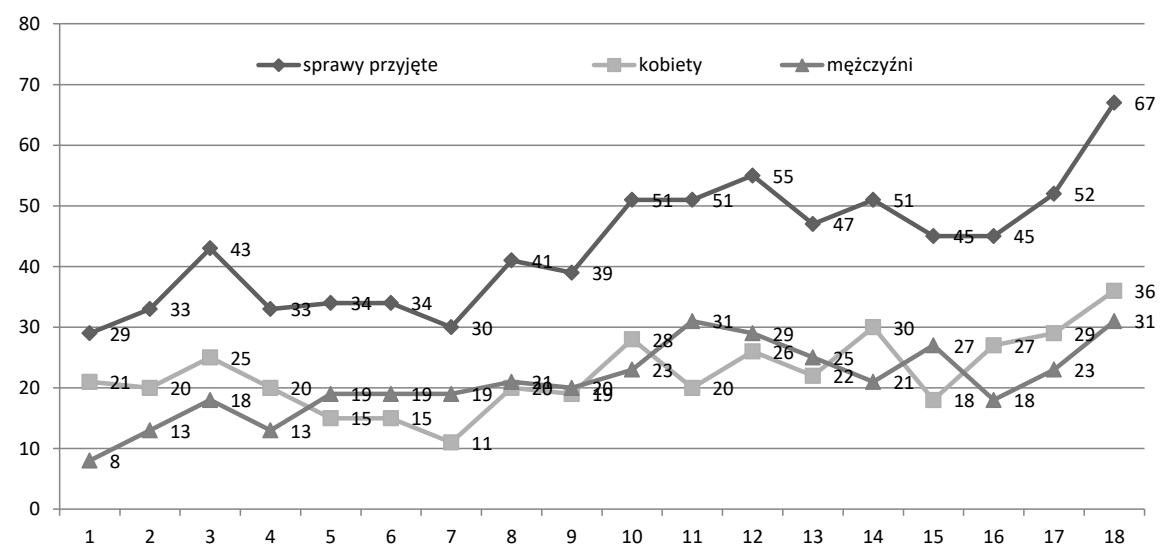

Wykres 19. Udział procentowy spraw wniesionych przez kobiety i przez mężczyzn w latach 1966-1983

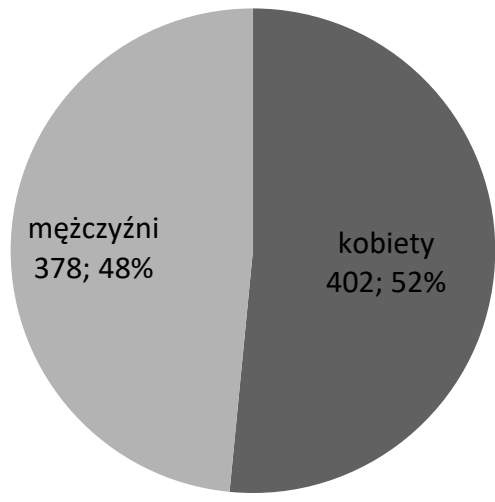


Łącznie od 1966 roku do 1983 roku zostało przyjętych 780 spraw, co stanowi o ponad 230 spraw więcej niż w poprzednio omawianym okresie. Należy ponadto nadmienić, że to okres o 2 lata krótszy od poprzednio omawianego. Ciągły wzrost liczby spraw ma charakter falowy z tendencją ku wzrostowi; widoczne jest to zwłaszcza w 3 stadiach: w latach 1965-1968, 1972-1977 oraz po 1981 roku [por. Wykres 18, Tabela 5].

Tabela 5. Sprawy złożone i przyjęte w latach 1966-1983

\begin{tabular}{|c|c|c|c|}
\hline RoK & SPRAWY PRZYJĘTE & Ковіету & MĘŻZZZYŹNI \\
\hline 1966 & 29 & 21 & 8 \\
\hline 1967 & 33 & 20 & 13 \\
\hline 1968 & 43 & 25 & 18 \\
\hline 1969 & 33 & 20 & 13 \\
\hline 1970 & 34 & 15 & 19 \\
\hline 1971 & 34 & 15 & 19 \\
\hline 1972 & 30 & 11 & 19 \\
\hline 1973 & 41 & 20 & 21 \\
\hline 1974 & 39 & 19 & 20 \\
\hline 1975 & 51 & 28 & 23 \\
\hline 1976 & 51 & 20 & 31 \\
\hline 1977 & 55 & 26 & 29 \\
\hline 1978 & 47 & 22 & 25 \\
\hline 1979 & 51 & 30 & 21 \\
\hline 1980 & 45 & 18 & 27 \\
\hline 1981 & 45 & 27 & 18 \\
\hline 1982 & 52 & 29 & 23 \\
\hline 1983 & 67 & 36 & 31 \\
\hline Razem & 780 & 402 & 378 \\
\hline
\end{tabular}




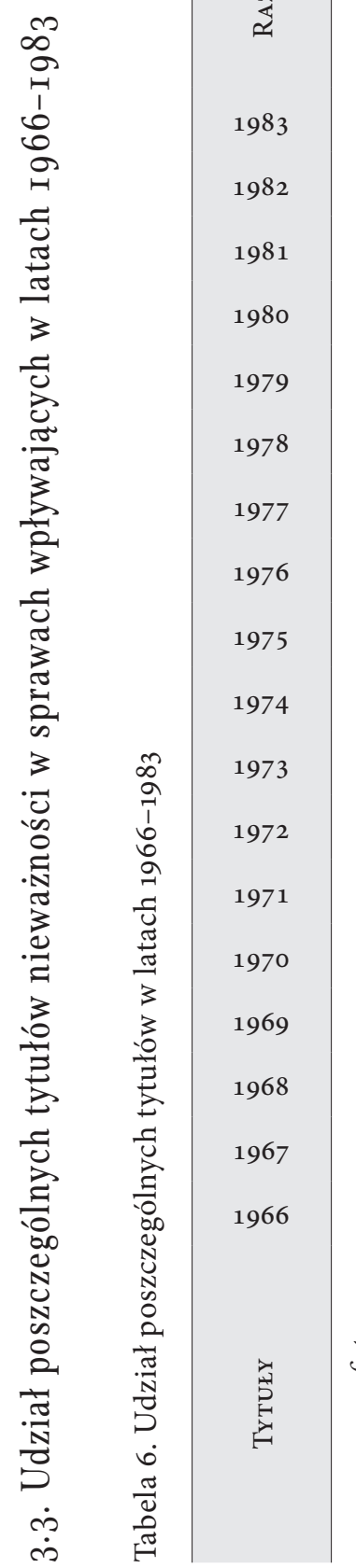

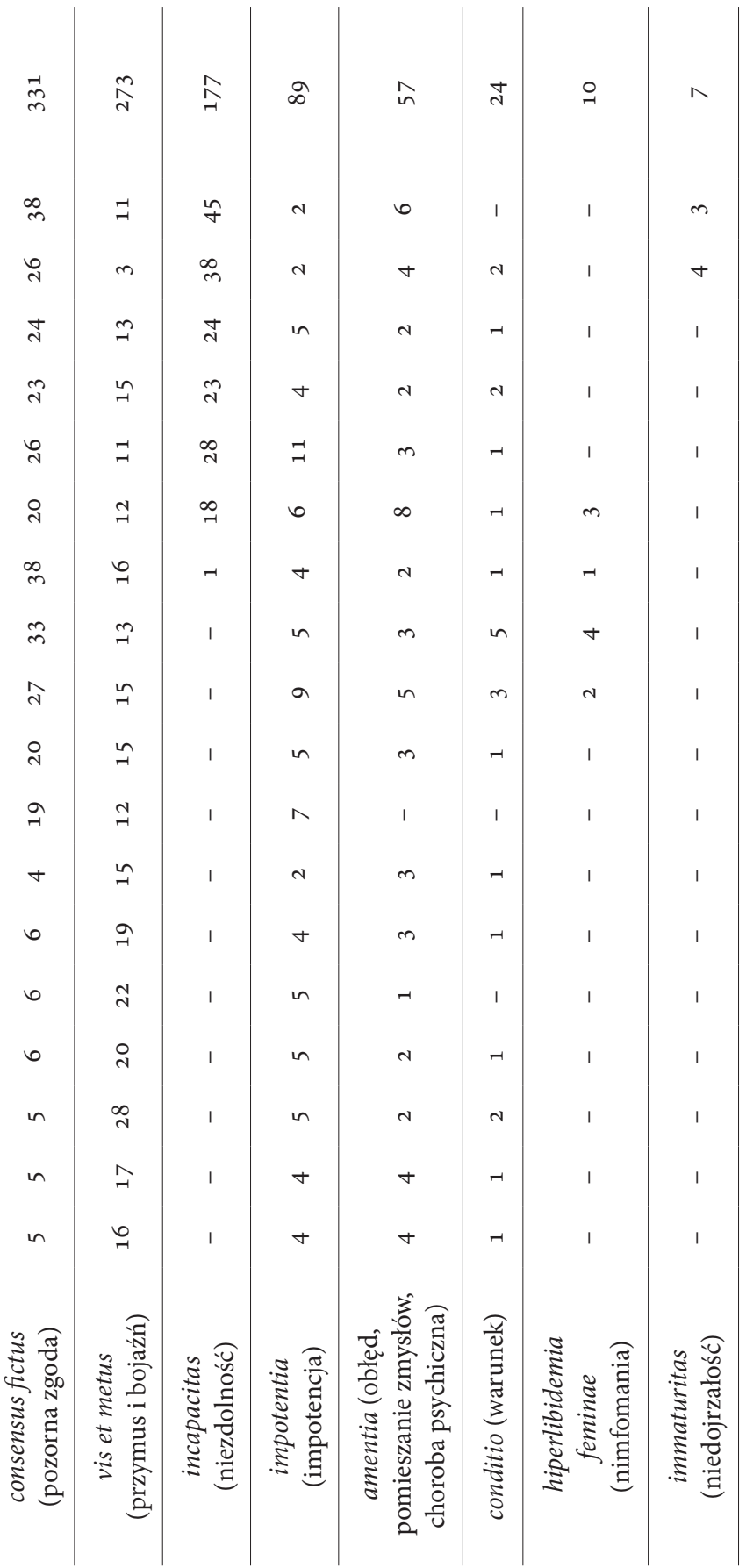




\begin{tabular}{|c|c|c|c|c|c|c|c|c|}
\hline 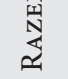 & in & $m$ & N & N & N & $r$ & - & - \\
\hline 1983 & 1 & 1 & 1 & 1 & 1 & 1 & 1 & 1 \\
\hline 1982 & 1 & 1 & -1 & 1 & 1 & 1 & 1 & 1 \\
\hline 1981 & 1 & 1 & 1 & 1 & 1 & 1 & 1 & 1 \\
\hline 1980 & 1 & 1 & 1 & 1 & 1 & 1 & 1 & 1 \\
\hline 1979 & 1 & 1 & 1 & 1 & 1 & 1 & 1 & 1 \\
\hline 1978 & 1 & -1 & 1 & 1 & 1 & 1 & 1 & 1 \\
\hline 1977 & - & N & -1 & 1 & $N$ & 1 & 1 & -1 \\
\hline 1976 & $N$ & 1 & 1 & 1 & 1 & 1 & 1 & 1 \\
\hline 1975 & 1 & 1 & 1 & 1 & 1 & -1 & 1 & 1 \\
\hline 1974 & 1 & 1 & 1 & 1 & 1 & 1 & - & 1 \\
\hline 1973 & -1 & 1 & 1 & - & 1 & 1 & 1 & 1 \\
\hline 1972 & 1 & 1 & 1 & 1 & 1 & 1 & 1 & 1 \\
\hline 1971 & 1 & 1 & 1 & 1 & 1 & 1 & 1 & 1 \\
\hline 1970 & 1 & 1 & 1 & $\dashv$ & 1 & 1 & 1 & 1 \\
\hline 1969 & 1 & 1 & 1 & 1 & 1 & 1 & 1 & 1 \\
\hline 1968 & 1 & 1 & 1 & 1 & 1 & 1 & 1 & 1 \\
\hline 1967 & 1 & 1 & 1 & 1 & 1 & 1 & 1 & 1 \\
\hline 1966 & -1 & 1 & 1 & 1 & 1 & 1 & 1 & 1 \\
\hline 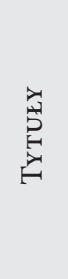 & 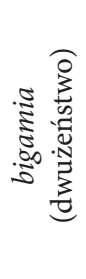 & 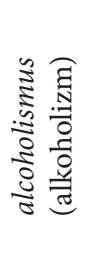 & 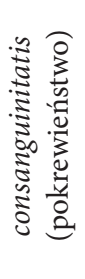 & 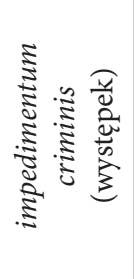 & 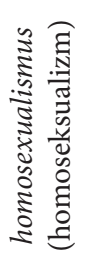 & 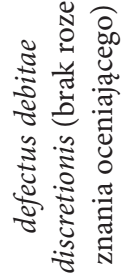 & 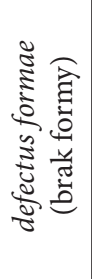 & 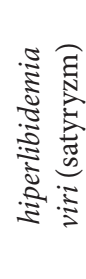 \\
\hline
\end{tabular}




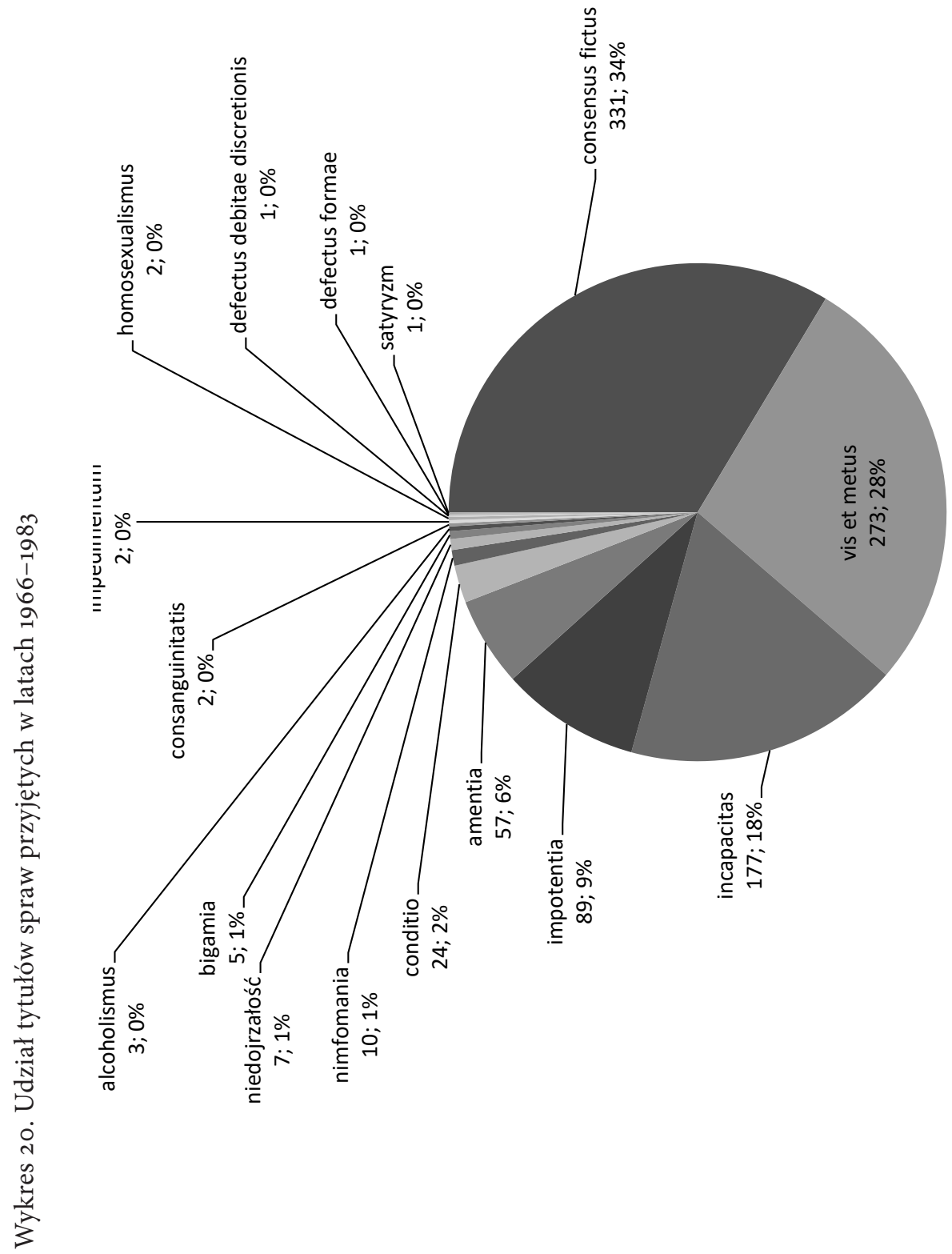


W opisywanym okresie zauważamy tendencję łączenia takich zjawisk jak nimfomania, satyryzm, homoseksualizm czy alkoholizm z pozorną zgodą (w zestawieniu umieszczone osobno), a także pojawienie się w latach 7o. tytułu niezdolności do podjęcia istotnych obowiązków małżeńskich, który zaczął w krótkim czasie odgrywać znaczącą rolę wśród rozpatrywanych przyczyn nieważności małżeństwa. Ponad połowę spraw, bo aż 60 proc., stanowią te z tytułów pozornej zgody oraz przymusu i bojaźni. Jednakże mimo braku odpowiedniego kanonu w kodeksie blisko 20 proc. spraw dotyczy niezdolności do podjęcia istotnych obowiązków małżeńskich, mimo że tytuł ten pojawia się dopiero w drugiej połowie lat 70. [por. Tabela 6, Wykres 20].

Na wokandzie w omawianym czasie pozostaje w poszczególnych latach średnio po 98 spraw na rok, $\mathrm{z}$ tendencją do powolnego, ale regularnego ich narastania od 1977 roku do 1983 roku [por. Wykres 21].

Wykres 21. Liczba pozostających spraw w latach 1966-1983

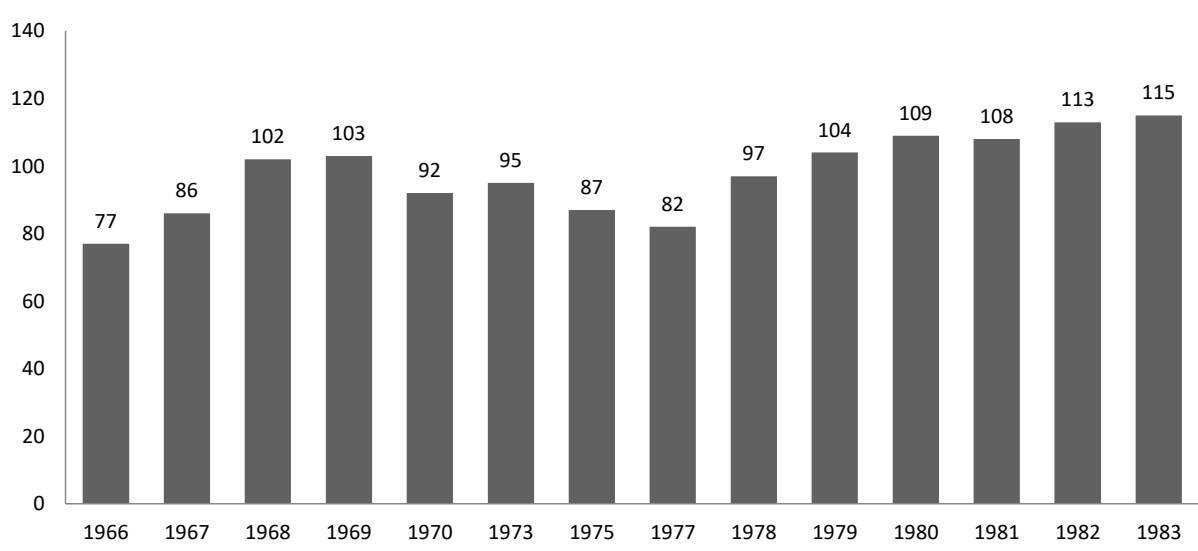

\section{3·4. Zakończenie instancji}

W omawianym czasie obserwujemy wzrost wyroków, których jest ponad 200 więcej niż do zakończenia soboru [por. Tabela 7 i Tabela 4]. Natomiast na identycznym poziomie pozostaje bilans wyroków stwierdzających nieważność małżeństwa względem wyroków potwierdzających ważność i obowiązywalność zaskarżonego małżeństwa [por. Wykres 23]. Zauważalny jest spadek liczby spraw bez wyroku, ale wynika to ze zmiany 
praktyki sądowej, gdy sprawy były przez sędziów analizowane i oddalane przed formalnym ich zarejestrowaniem $\mathrm{w}$ księgach procesowych [por. Tabela 7, Wykres 22].

Tabela 7. Zakończenie instancji w latach 1966-1983

\begin{tabular}{|c|c|c|c|c|}
\hline RoK & $\begin{array}{c}\text { WYROK } \\
\text { POZYTYWNY }\end{array}$ & $\begin{array}{c}\text { WYROK } \\
\text { NEGATYWNY }\end{array}$ & $\begin{array}{l}\text { ZAKOŃCZONE } \\
\text { BEZ WYROKU }\end{array}$ & $\begin{array}{c}\text { VOTA SUPER } \\
\text { RATO }\end{array}$ \\
\hline 1966 & 14 & 6 & 2 & 5 \\
\hline 1967 & 22 & 5 & 1 & 1 \\
\hline 1968 & 18 & 9 & 3 & 7 \\
\hline 1969 & 25 & 8 & 9 & 4 \\
\hline 1970 & 22 & 11 & 3 & 4 \\
\hline 1971 & 21 & 11 & 5 & 3 \\
\hline 1972 & 16 & 13 & 3 & 3 \\
\hline 1973 & 14 & 12 & 2 & 4 \\
\hline 1974 & 18 & 11 & 5 & 5 \\
\hline 1975 & 22 & 11 & 4 & 1 \\
\hline 1976 & 28 & 9 & 7 & 2 \\
\hline 1977 & 21 & 14 & 4 & 1 \\
\hline 1978 & 27 & 12 & 8 & 1 \\
\hline 1979 & 20 & 14 & 2 & 5 \\
\hline 1980 & 22 & 15 & 9 & 4 \\
\hline 1981 & 27 & 7 & 6 & 1 \\
\hline 1982 & 25 & 15 & 4 & 5 \\
\hline 1983 & 19 & 9 & 6 & - \\
\hline Razem & 381 & 192 & 83 & 56 \\
\hline
\end{tabular}




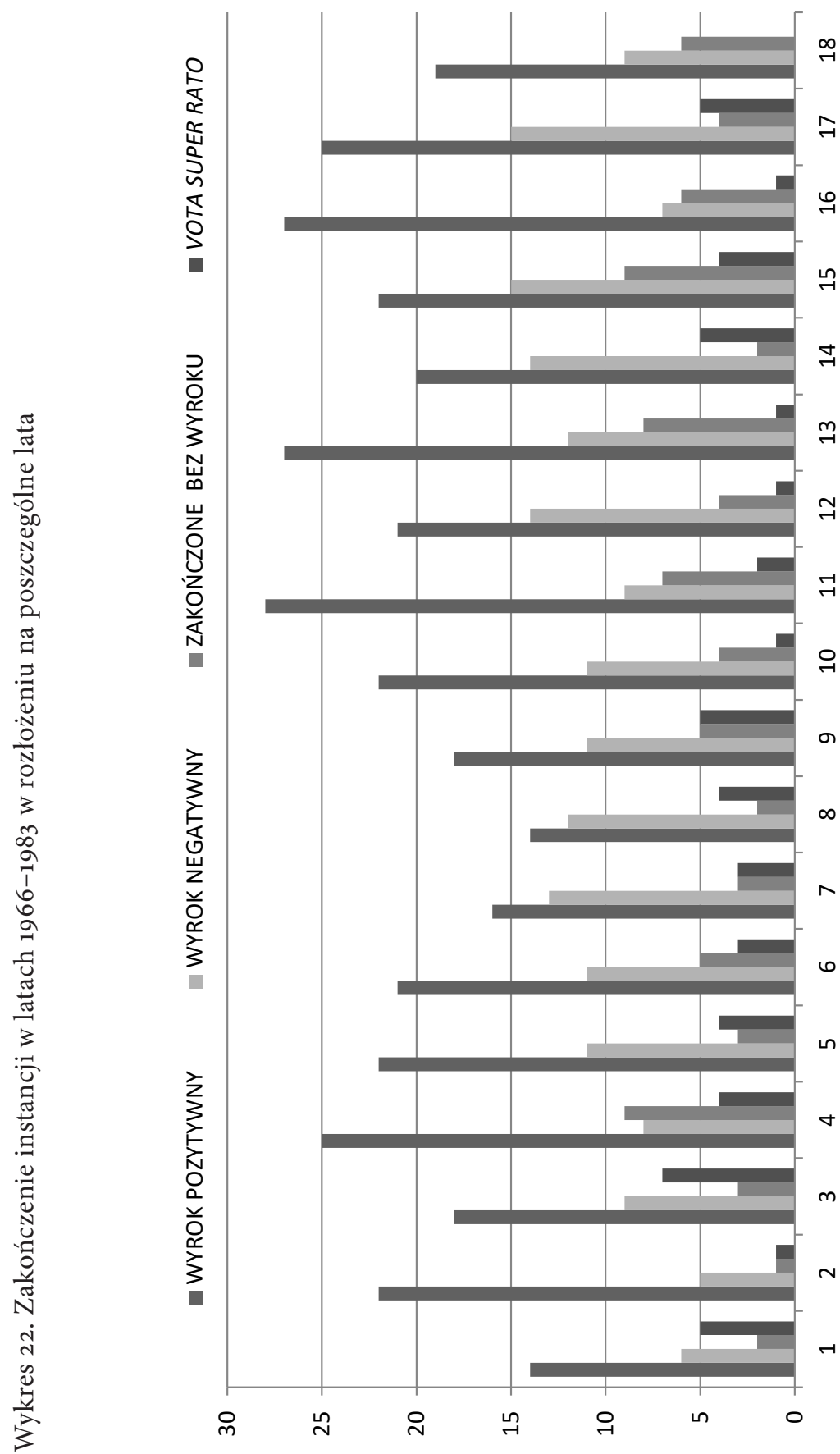


Wykres 23. Bilans wyroków pozytywnych i negatywnych w latach 1966-1983

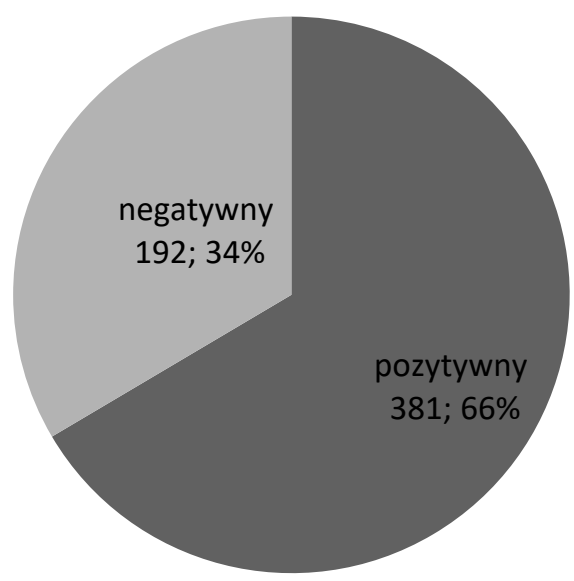

W wyrokach wydawanych w interesującym nas czasie zauważamy próby łączenia nimfomanii, alkoholizmu czy niezdolności jako takiej (immaturitas ad munera coniugalia adimplenda) z pozorną zgodą. Ma to miejsce w kilku przypadkach już od 1977 roku. W kolejnych latach prowadzi to do wyszczególniania osobnego tytułu w sprawozdaniach ówczesnego oficjała Sądu Diecezjalnego księdza doktora Piotra Gajdy do Sygnatury Apostolskiej ${ }^{27}$, co jest efektem uwzględniania prac Komisji do spraw Rewizji Kodeksu i stopniową zapowiedzią tytułów związanych z nowym kan. 1095 w kodeksie Jana Pawła II z 1983 roku, które można było zaaplikować do spraw rozpoczętych przed 1983 rokiem, a mających swoje rozstrzygnięcie w okresie po wejściu w życie nowego kodeksu. Dlatego warto prześledzić, jak przedstawiały się tytuły w poszczególnych latach [por. Tabela 8 , Tabela 9].

${ }^{27}$ Por. P. Gajda, Relatio annualis de activitate Tribunalis za lata 1979-1983 (oryginały sprawozdań wysłane do Sygnatury Apostolskiej, kopie przechowywane u oficjała Sądu Diecezjalnego). 


\begin{tabular}{|c|c|c|c|c|c|}
\hline Suma & $\stackrel{8}{\circ}$ & $\hat{\imath}$ & in & $\dddot{q}$ & ले \\
\hline 1983 & + & $N$ & 1 & N & $\exists$ \\
\hline 1982 & in & 0 & in & $m$ & $\exists$ \\
\hline 1981 & 0 & $\infty$ & - & -1 & $\exists$ \\
\hline 1980 & 6 & $\wedge$ & $\nabla$ & N & $m$ \\
\hline 1979 & $\wedge$ & 익 & in & 1 & $r$ \\
\hline 1978 & $\nabla$ & $\stackrel{\infty}{\infty}$ & -1 & N & $\mathrm{N}$ \\
\hline 1977 & $\wedge$ & 욱 & - & N & 1 \\
\hline 1976 & $\wedge$ & $\stackrel{\text { in }}{\rightarrow}$ & -1 & $\forall$ & 1 \\
\hline 1975 & $a$ & in & $N$ & t & 1 \\
\hline 1974 & $\infty$ & + & $\infty$ & $n$ & 1 \\
\hline 1973 & $\stackrel{\circ}{\sim}$ & -1 & $\sigma$ & $m$ & 1 \\
\hline 1972 & $\stackrel{\circ}{\circ}$ & $\rightarrow$ & $\nabla$ & $m$ & 1 \\
\hline 1971 & I & $n$ & $n$ & in & 1 \\
\hline 1970 & $\stackrel{0}{-1}$ & N & N & $m$ & 1 \\
\hline 1969 & $\stackrel{0}{0}$ & $n$ & $\sigma$ & -1 & 1 \\
\hline 1968 & $\stackrel{\sim}{-}$ & in & $\wedge$ & 1 & 1 \\
\hline 1967 & $\rightarrow$ & $m$ & -1 & $m$ & 1 \\
\hline 1966 & $\wedge$ & $N$ & $\sigma$ & N & 1 \\
\hline 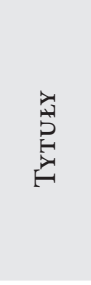 & 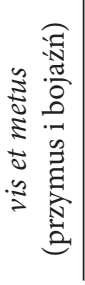 & 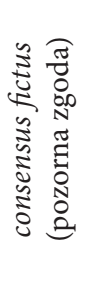 & 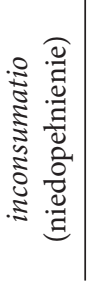 & 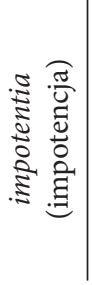 & 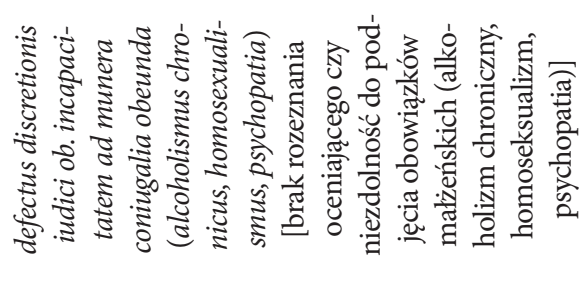 \\
\hline
\end{tabular}




\begin{tabular}{|c|c|c|c|c|c|}
\hline$\stackrel{n}{\wedge}$ & $\stackrel{\circ}{\sim}$ & in & $\neg$ & $\rightarrow$ & -1 \\
\hline 1 & 1 & 1 & 1 & 1 & 1 \\
\hline$\dashv$ & $r$ & 1 & 1 & 1 & 1 \\
\hline-1 & 1 & 1 & 1 & 1 & 1 \\
\hline$n$ & $r$ & 1 & 1 & 1 & 1 \\
\hline-1 & $\rightarrow$ & 1 & 1 & 1 & 1 \\
\hline $\mathrm{N}$ & $\rightarrow$ & 1 & 1 & 1 & 1 \\
\hline$\dashv$ & 1 & N & 1 & 1 & $r$ \\
\hline$m$ & -1 & 1 & 1 & 1 & 1 \\
\hline $\mathrm{N}$ & -1 & $\dashv$ & 1 & 1 & 1 \\
\hline$m$ & 1 & 1 & 1 & - & 1 \\
\hline 1 & 1 & 1 & 1 & 1 & 1 \\
\hline 1 & 1 & 1 & 1 & 1 & 1 \\
\hline$\dashv$ & 1 & 1 & 1 & 1 & 1 \\
\hline $\mathrm{N}$ & 1 & 1 & 1 & 1 & 1 \\
\hline N & $m$ & 1 & 1 & 1 & 1 \\
\hline- & 1 & 1 & 1 & 1 & 1 \\
\hline $\mathrm{N}$ & $\rightarrow$ & 1 & $\neg$ & 1 & 1 \\
\hline 1 & 1 & $N$ & 1 & 1 & 1 \\
\hline 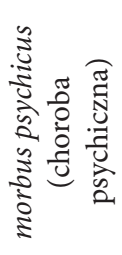 & 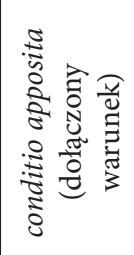 & 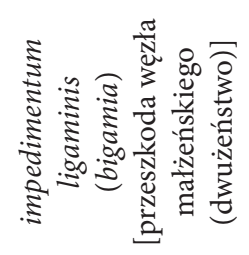 & 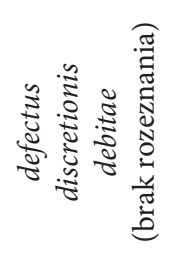 & 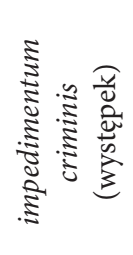 & 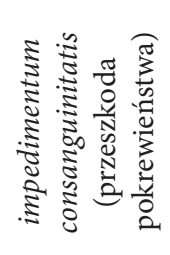 \\
\hline
\end{tabular}




\begin{tabular}{|c|c|c|c|}
\hline Suma & $\vec{I}$ & $\infty$ & $\underset{f}{\forall}$ \\
\hline 1983 & $\stackrel{\sim}{\sim}$ & $m$ & $a$ \\
\hline 1982 & $\stackrel{n}{\pi}$ & $n$ & $\stackrel{m}{-1}$ \\
\hline 1981 & 욱 & 0 & $\stackrel{-}{\circ}$ \\
\hline 1980 & $\underset{7}{\mathrm{~N}}$ & $\infty$ & 0 \\
\hline 1979 & $\underset{J}{\triangle}$ & $\wedge$ & ナ \\
\hline 1978 & $\stackrel{\oplus}{\rightarrow}$ & - & $\dashv$ \\
\hline 1977 & $\infty$ & $\nabla$ & 1 \\
\hline 1976 & in & $m$ & 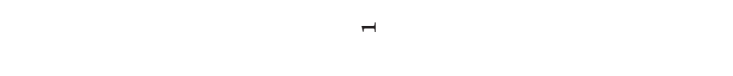 \\
\hline 1975 & in & 0 & 1 \\
\hline 1974 & 0 & $n$ & 1 \\
\hline 1973 & in & in & 1 \\
\hline 1972 & ה & $\infty$ & 1 \\
\hline 1971 & $n$ & $\wedge$ & I \\
\hline 1970 & N & $\nabla$ & 1 \\
\hline 1969 & N & $\wedge$ & I \\
\hline 1968 & - & $\nabla$ & 1 \\
\hline 1967 & $m$ & $m$ & 1 \\
\hline 1966 & $N$ & $N$ & 1 \\
\hline 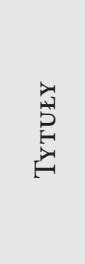 & 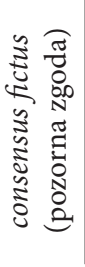 & 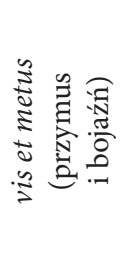 & 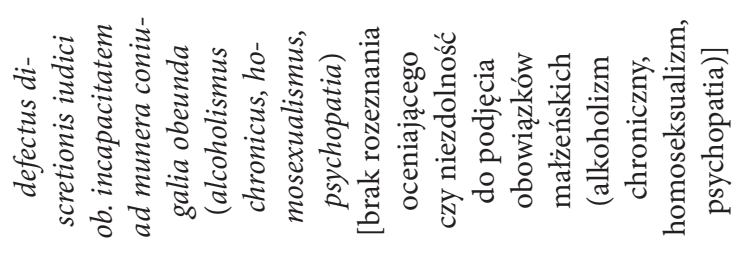 \\
\hline
\end{tabular}




\begin{tabular}{|c|c|c|c|c|c|}
\hline$\stackrel{\text { N }}{\text { in }}$ & $\cong$ & $\underset{工}{I}$ & 어 & -1 & $\rightarrow$ \\
\hline-1 & -1 & 1 & -1 & 1 & 1 \\
\hline 1 & N & 1 & 1 & -1 & 1 \\
\hline 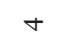 & $\neg$ & N & 1 & 1 & 1 \\
\hline$-r$ & -1 & $\dashv$ & $n$ & 1 & -1 \\
\hline 1 & 1 & 1 & $\rightarrow$ & 1 & 1 \\
\hline 1 & 1 & $m$ & 1 & 1 & 1 \\
\hline 1 & $\dashv$ & 1 & $n$ & 1 & 1 \\
\hline 1 & $N$ & $\neg$ & -1 & 1 & 1 \\
\hline 1 & $\neg$ & - & 1 & 1 & 1 \\
\hline- & 1 & -1 & 1 & 1 & 1 \\
\hline$m$ & - & 1 & 1 & 1 & 1 \\
\hline 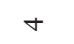 & 1 & 1 & 1 & 1 & 1 \\
\hline 4 & 1 & 1 & 1 & 1 & 1 \\
\hline$m$ & $m$ & -1 & -1 & 1 & 1 \\
\hline 1 & -1 & 1 & 1 & 1 & 1 \\
\hline 6 & 1 & 1 & 1 & 1 & 1 \\
\hline 1 & 1 & $\neg$ & 1 & 1 & 1 \\
\hline-1 & -1 & $\neg$ & 1 & 1 & 1 \\
\hline 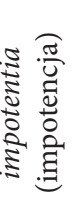 & 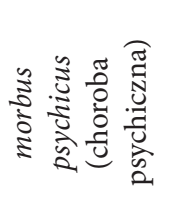 & 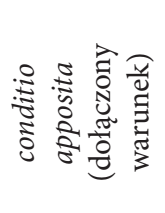 & 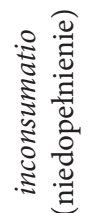 & 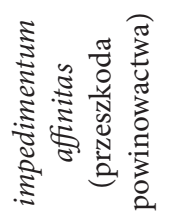 & t: \\
\hline
\end{tabular}


W dalszym ciągu najczęstszą przyczyną stwierdzenia nieważności zawartego małżeństwa jest tytuł przymusu i bojaźni, ale traci on w porównaniu do pierwszego $\mathrm{z}$ omawianych okresów 10 pkt proc. Należy także podkreślić, że na początku lat 7o. zaczyna zyskiwać na znaczeniu w wyrokach tytuł pozornej zgody, w ogólnym rozrachunku notując nieco ponad 20 proc. wydawanych wyroków, a więc zyskując nieco poniżej 20 pkt proc. w stosunku do okresu pierwszego. Dalej bez większych zmian plasują się sprawy przygotowywane do dyspensy papieskiej i impotencja. Natomiast 9 proc. notują tytuły stanowiące podstawę przyszłego kan. 1095 nowego kodeksu, dynamicznie wkraczając po połowie lat 70. [por. Wykres 24].

Nieco inna sytuacja przedstawia się w zakresie sentencji negatywnych. Najwięcej potwierdzeń ważności małżeństwa występuje z tytułu pozornej zgody, dalej przymusu i bojaźni oraz wspomnianych nowych tytułów zapewne jest to efekt ich zakorzeniania w jurysprudencji kanonicznej [por. Wykres 25].

Wykres 24. Udział poszczególnych tytułów w wyrokach pozytywnych w latach 1966-1983

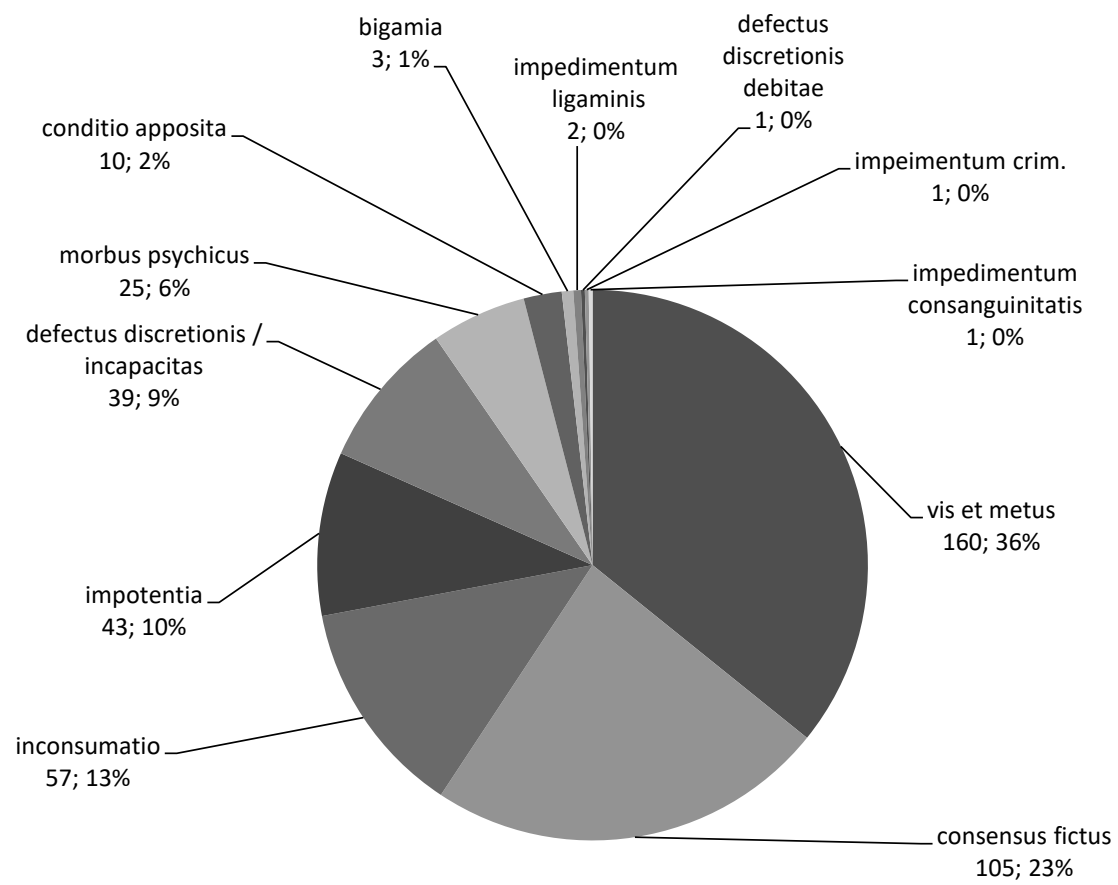


Wykres 25. Udział poszczególnych tytułów w wyrokach negatywnych w latach 1966-1983

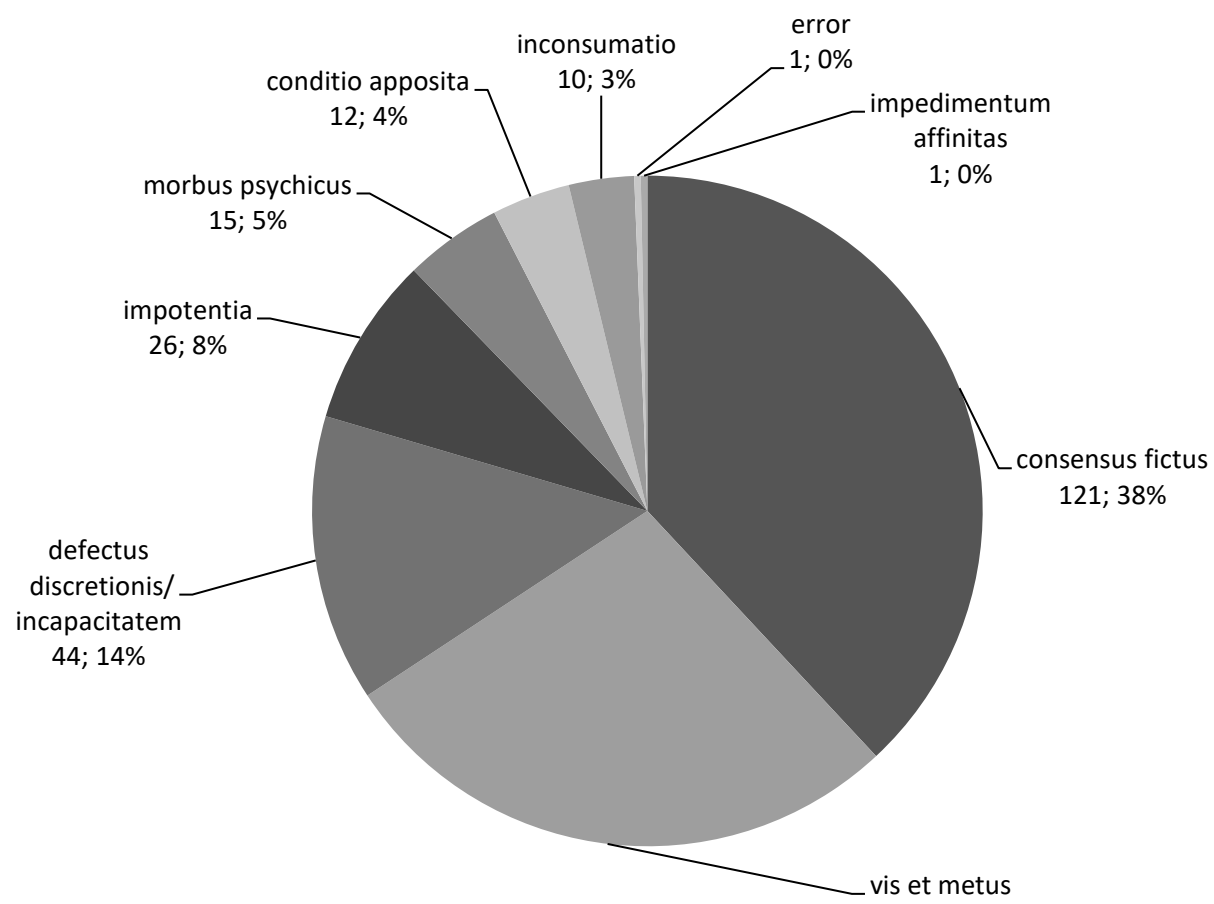

$88 ; 28 \%$

Niewątpliwie zebrany materiał daje obraz ogromu pracy, jaką przez lata wykonywali pracownicy Sądu Diecezjalnego w Tarnowie, stawiając czoła nowym wyzwaniom czasu i zmieniających się uwarunkowań. Należy zauważyć, że przedstawione zestawienie procesów z lat 1945-1983, chociaż bazuje na różnych dokumentach sądowych, natrafia na pewne braki w systematycznej dokumentacji, jednak przez uzgodnienie danych zawartych w skorowidzach, sprawozdaniach i księgach procesowych daje obraz aktywności trybunału w wyznaczonym zakresie czasowym. Bardziej szczegółowe zaprezentowanie uwidocznionych problemów wymagałoby sięgnięcia do akt procesowych. 
